\title{
National Wellbeing and International Sports Events
}

\author{
Georgios Kavetsos ${ }^{1}$ and Stefan Szymanski ${ }^{2}$
}

August 2008

\begin{abstract}
The widely proclaimed economic benefits of hosting major sporting events have received substantial criticism by academic economists and have been shown to be negligible, at best. The aim of this paper is to formally examine the existence of another potential impact: national wellbeing or the so-called "feelgood" factor. Using data on self-reported life satisfaction (happiness) for twelve European countries we test for the impact of hosting and of national athletic success on happiness. Our data covers three different major events: the Olympic Games, the FIFA World Cup and the UEFA European Championship. We find that the "feelgood" factor associated with hosting football events is large and significant, but that the impact of national athletic success on happiness, while correctly signed, is statistically insignificant.
\end{abstract}

JEL Classification Codes: D60, I31, L83

Keywords: Life satisfaction; Happiness; Feel-good factor; Sporting events; Economic impact

${ }^{1}$ Georgios Kavetsos, Cass Business School, City University, London, 106 Bunhill Row, London, EC1Y 8TZ, U.K

${ }^{2}$ Stefan Szymanski, Tanaka Business School, Imperial College London, South Kensington campus, SW7 2AZ, UK. Tel : (44) 207594 9107, Fax: (44) 207823 7685, e-mail: szy@imperial.ac.uk. 


\section{Introduction}

"We conclude that government should set itself two overarching objectives:

- a major increase in participation in sport and physical activity, primarily because of the significant health benefits and to reduce the growing costs of inactivity; and

- a sustainable improvement in success in international competition, particularly in the sports which matter most to the public, primarily because of the 'feelgood factor' associated with winning”.

DCMS/Strategy Unit (2002)

Worldwide, Government intervention in sport is substantial. The rationale for that support remains controversial. Until the mid-twentieth century it was driven to a large extent by the demand for military preparedness, but in most of the world that justification is no longer advanced. In its place, a wide range of social and political benefits have been suggested. As the quote from the British government report attests, promoting physical activity because of the health benefits is one rationale. However, since large amounts of public subsidies are often associated with hosting major sporting events, which in themselves do little to boost participation, additional justification is required. There has been a sustained intellectual argument in recent years between economists and boosters of all kinds about the alleged economic benefits of major events, and the balance of evidence points to the conclusion that these benefits are negligible or non-existent.

In this paper we consider a more fundamental rationale for hosting major sporting events- happiness. The "feelgood" factor associated with national sporting triumphs and event hosting is often discussed in the media and has been the theme of recent academic research (e.g. Maenning and Porsche, 2008), but this is the first study to measure these relationships empirically. This feelgood emotion may arise from a number of causes: the enjoyment of attending events, of being involved as a volunteer organizer, enjoyment of the proximity of the events even if one does not attend, cultural showcases, and national pride.

Previous work on happiness and sport has concentrated on athletes' happiness and on medical studies of individuals during sports events. For example, even though the silver medal is ranked higher than the bronze, a study of the 1992 Olympics by Medvec et al. (1995) found that bronze medalists are happier than silver medalists. The most plausible justification for this result is the potential alternative for each medalist- silver medalists are unhappy that they narrowly missed out on the gold medal, whereas bronze are simply happy to be present on the medal stand. From another perspective, recent medical research suggests that people care about sports events; the latter having an impact on individual psychology and subsequently on health. For example, it has been shown that occurrences of myocardial infarctions are significantly higher following a stressful sports event (Witte et al., 2000; Carroll et al., 2002; Kirkup and Merrick, 2003; Wilbert-Lampen et al., 2008). At the other extreme, Fernquist (2000) provides evidence that better team performance is associated with lower suicide and homicide rates.

This study considers two hypotheses: first, that the success of nation's athletes produces a measurable increase in reported happiness among citizens of that nation; second, that simply acting as host produces an increase in happiness among the citizens of the host nation. To test this we use pooled cross section data of surveys of reported happiness in European countries from the last 30 years. We are interested in the success 
of national teams in the summer Olympics and major international football tournaments; the FIFA World Cup and the UEFA European Championship.

We find limited support for the hypothesis that athletic success impacts significantly on reported happiness. However, we find that hosting major events, in particular the marquee football tournaments, is associated with increased reported happiness in the period following the event. We conclude that it is not winning the game, but playing the host, that creates the feelgood factor. While this may provide some comfort to boosters eager to attract major events with government support, this also suggests that the public investment in athletic success is not the crowd pleaser that it is often claimed to be. Furthermore, we find no evidence of a lasting happiness effect from hosting.

Section 2 reviews the literature and evidence on the economic impact of sporting events and that on happiness. Section 3 explains our methodology and section 4 our results. Section 5 concludes.

\section{The Economics of Sport and Happiness}

\subsection{Economic Impact of Sports Events}

It has long been claimed by promoters that public investments in major sports events will produce net economic benefits in the manner of Keynesian injections and multiplier effects. In this section we outline the theory and evidence behind four claims about increased economic activity through hosting sports events (see Matheson (2006) for an overview).

(a) Employment and Wages: It is claimed that mega projects will lead to the creation of job opportunities; short term ones in the construction sector and long term ones in spin-off businesses (e.g. tourist memorabilia and restaurants) (Argue, 1983). Rappaport and Wilkerson (2001), Chapin (2002) and Coates and Humphreys (2003) point out that while jobs might be created, these must be netted off against jobs lost due to substitution effects. Given budget constraints, increased expenditure by consumers on sports related events will reduce spending elsewhere and increase job losses in non-sports related businesses. In fact, Crompton (1995, 2001) argues that businesses will not be willing to hire more full-time staff due to an increase in demand caused by a single sporting event.

In addition, Siegfried and Zimbalist (2000) note that the multiplier for sports related expenditures may be lower than that of other types of expenditures. This is because sports related expenditures are more likely to leak out of the local economy than non-sports ones (e.g. construction workers may be less likely to live in the local area, and therefore are not expected to spend their income locally) (Matheson and Baade, 2004). Moreover, while the construction phase may generate some employment, long term employment related to sport facilities is likely to be part-time, casual, low skilled, and low waged, thus not contributing in the improvement of the quality of full-time jobs (Baade, 1996; Hall, 2006; Whitson and Horne, 2006). Given these facts it is not surprising that the evidence suggests that the development and construction of stadiums does not generate a net addition to economic activity (Baade and Dye, 1990; Rosentraub, 1994; Crompton, 1995; Baade, 1996; Coates and Humphreys, 1999; Lertwachara and Cochran, 2007).

(b) Sports Stadium and their legacy: The right to host a major event is usually won in competition with rival cities or countries. In this "beauty contest" the winner is 
frequently the bidder that offers the most lavish showcase for the event, usually a state of the art sports facility of an impressive architectural conception and size (Chalkley and Essex, 1999; Whitson, 2004). Often the greatest difficulty once the event is over is to find a suitable tenant for the facility in order to cover its maintenance costs (Thornley, 2002). ${ }^{1}$ For example, in order to cover its annual maintenance costs, Sydney's Superdome needs to host nearly one event every weekend (Telloglou, 2004). ${ }^{2}$ Almost by definition the "legacy" utilisation of facilities constructed to host some of the world's biggest sporting events can not match this level of demand. On a study of the 2002 FIFA World Cup, Manzenreiter and Horne (2005) conclude that the construction of sports stadia for mega events leads to "unfulfilled promises of reviving the economy".

(c) Tourism: Through marketing and media exposure the host city may be able to attract tourists both during and after the event. Tourists are assumed to spend money in the local economy, hence having an economic multiplier effect (Kartakoullis et al., 2003). However, this issue is often confused by a failure to correctly define the region impacted. For example, if one considers the impact on the London economy of the 2012 Olympics, there will be many visitors from outside the area injecting money into the capital. However, if the focus is the impact in the UK economy, one should net off UK visitors, since they are simply diverting their expenditures from one region to another. The bigger the region considered, the smaller the number of additional visitors generated.

Moreover, one should account for time-switchers (those who would have come anyway, just at a different date) and casual tourists (those who would have come at this date whether or not the event wastaking place) whose expenditures cannot be fully attributed to the event, as well as considering the possibility that the event itself might be crowding-out a fraction of others (Crompton, 1995; Matheson, 2002; Siegfried and Zimbalist, 2002).

(d) Infrastructure Investments and Urban Regeneration: Major sporting events involve the movement of large numbers of people in confined spaces and therefore demand a high standard of public infrastructure funded by government. The associated investments include accommodation, efficient transportation and telecommunications systems (Roche, 1992). It has also been suggested that cities/nations often bid to stage sports events solely in order to achieve regeneration plans and stimulate tourism in the post-event period (Essex and Chalkley, 1998; Chalkley and Essex, 1999; Burbank et al., 2002). The first Olympic host cities claiming to follow such a strategy were Rome (1960 Olympics) and Tokyo (1964 Olympics).

There are good reasons to be skeptical about these claims. Urban regeneration requires investment in facilities for day-to-day living rather than showcase events. Furthermore, public expenditures have to be funded out of taxation, and increased taxes tend to crowd out private expenditures. The Montreal 1976 Games were an economic disaster precisely because the huge tax burden imposed by paying for the games was not matched by any local stimulus to growth caused by the event itself. It is also likely that, because of the higher prices associated with construction services before the Games,

\footnotetext{
${ }^{1}$ Demolishing facilities is not an uncommon practice either. As an example consider the case of the Velodrome following the 1956 Melbourne Olympics (Chalkley and Essex, 1999).

${ }^{2}$ Also known as the Acer Arena, Sydney's Superdome is Australia's largest indoor arena. Officially opened in 1999 for the Sydney 2000 Olympics, it can host a maximum of 21,000 seated spectators.
} 
some investment projects not relevant to the Olympics might be postponed or even deterred (Blake, 2005).

Even if some benefits from hosting are acknowledged, one should consider the opportunity cost of public funds, which could be used to finance hospitals and schools, thus generating job placements, enhancing wellbeing and human capital, and potentially increasing productivity (Coates and Humphreys, 1999; Ingerson, 2001; Essex and Chalkley, 2003; Whitson, 2004; PriceWaterhouseCoopers, 2004). To quote Baade and Matheson (2002): “once opportunity costs are considered with the possibility that Olympic venues could compete for limited leisure dollars, the Olympics could actually generate a cumulative long-term job loss". ${ }^{3}$

In sum, arguments supporting the view that hosting major sporting events will produce significant increases in economic activity rest on weak foundations. However, the economic argument for hosting mega events should in any case be based on the argument that it will produce a net increase in welfare; and welfare may be only weakly correlated with economic activity. On the face of it, it would seem to be a much stronger justification for public spending on these events if it could be claimed not that they will make us rich, but that they will make us happy.

\subsection{Economics of Happiness}

To measure happiness, the question usually posed in surveys is a variant of the following: "Taking all things together, how would you say things are these days - would you say you are happy, quite happy, or not very happy?", where responses are treated in an ordinal manner. (Frey and Stutzer, 2002; Layard, 2005a). ${ }^{4}$

Survey methods attempting to gather life satisfaction levels are not free of criticism. Human genes may well predetermine psychological tendencies; the words 'happiness' and 'satisfaction' might have different interpretations in different languages so that cross country comparisons may be misleading; individuals, rather than reporting their actual satisfaction level, might report either the satisfaction level they are expected to have, given their status, or the level others consider them having; and people may be either understating or overstating their true state of happiness when specifically asked to report it (see Bertrand and Mullainathan, 2001; Frank, 2005; Layard, 2005b; Veenhoven, 2005).

In defense of cross-country happiness studies it is argued that, given the large number of people being randomly surveyed at the national level, any potential biases become non-systematic and the signal-to-noise ratio reaches a sufficient standard to make inferences and comparisons across groups and countries valid (Di Tella and MacCulloch, 2006; Kahneman and Krueger, 2006). The validity of the happiness scale level is supported in van Praag (1991), arguing that verbal labels used in questionnaires, e.g. 'very happy', are on average successfully translated into numerical values.

Personality factors, such as age, gender, level of education attained, marital status, employment status, and personal income levels, are usually controlled for in the estimation model in order to reduce biases due to unobserved heterogeneity between respondents. Previous research has indicated that married people, those on higher income groups, females, the higher educated, the self-employed, the retired and housewives tend

\footnotetext{
${ }^{3}$ Developing countries are likely to face larger opportunity costs (Matheson and Baade, 2004).

${ }^{4}$ In line with previous papers, the terms 'happiness', 'life satisfaction', 'utility' and 'well-being' are used interchangeably here (Easterlin, 2005).
} 
to be happier on average. Moreover, happiness appears to be U-shaped in age- the minimum being observed around age 30 (Oswald, 1997). Importantly, researchers find that unemployment leads to unhappiness not only because of the income effects but because of the social status associated with not being able to find work (see Clark and Oswald (1994) and Winkelmann and Winkelmann (1998) for a relevant analysis using panel data).

On the impact of macroeconomic indicators on happiness, a series of studies estimate that within nations wealthier individuals are happier, although the relationship exhibits diminishing returns (Easterlin, 1974, 1995; Di Tella et al., 2001). Moreover, there is evidence that individuals care more about their relative rather than absolute level of income (Easterlin, 1995; Clark and Oswald, 1996; Blanchflower and Oswald, 2000; Luttmer, 2005). ${ }^{5}$ Even though GDP per capita has been rising- fairly consistently- since the end of WWII, average self-reported happiness has remained more or less constant. That is, people do not seem to become happier as they become richer (Easterlin, 1974, 1995, 2005; Layard, 2005b). The so-called 'Easterlin Paradox' seems to exist for most Western economies, including the US, the UK, Germany and Japan (Easterlin, 1995; Blanchflower and Oswald, 2004; Frank, 2005). ${ }^{6}$ Research also shows that the unemployment rate in the wider population has adverse effects on the well-being of the individual (including those in employment: Di Tella et al., 2001; Di Tella et al., 2003). These authors also find a negative effect on happiness arising from increases in inflation.

Lately, the literature has focused on identifying the impact of other factors on wellbeing. For example, Frey and Stutzer (2000) and Di Tella and MacCulloch (2005a) concentrate on the participation of residents in policy decisions and the sensitivity between right- and left-wing supporters on macro policies, respectively. Blanchflower and Oswald (2004) measure the impact of sexual activity on happiness levels of US citizens. Frey et al. (2004) test the effect of terrorist activities for some European countries. Di Tella and MacCulloch (2005b) investigate the impact of pollution on happiness. Oswald and Powdthavee (2006) test the theory of adaptation based on British individuals having experienced a disability. Frey et al. (2007) test the impact of television watching on happiness. Finally, Blanchflower and Oswald (2008) find an inverse relationship between happier nations and hypertension.

We add to this emerging branch of economics by focusing on the so far unexplored links between happiness and sporting events. In this paper we focus on the impact of sporting performance and hosting sporting events have on wellbeing as measured by stated levels of happiness.

\section{Data and Methodology}

The focus of our study is the effect of success in, and hosting of, the Olympic Games, the FIFA World Cup and the UEFA European Cup have on individuals' happiness. The happiness data used in this study is taken from the Eurobarometer Survey

\footnotetext{
${ }^{5}$ For example, consider a popular survey of Harvard University students on the decision to live in one of the following states: (a) in the one where you earn $\$ 50 \mathrm{k}$ and everybody else earns $\$ 25 \mathrm{k}$, or (b) in the one where you earn \$100k and everybody else earns \$250k. Even though personal income doubles from one state to the other, the majority of students chose the former to the latter (Solnick and Hemenway, 1998).

${ }^{6}$ For poor countries the assumption is that increases in income are more significant (Layard, 2005a; p. 33). Further research on the Easterlin Paradox includes Easterlin (2003), Frey and Stutzer (2005), Veenhoven (2005), Layard (2005b) and Di Tella and MacCulloch (2006), amongst others.
} 
Series, covering 12 countries: Belgium, Britain, Denmark, France, Germany, Greece, Ireland, Italy, Luxembourg, Netherlands, Portugal and Spain, and spanning the years 1974 to 2004. ${ }^{7}$ The Surveys are conducted on behalf of the European Commission in an attempt to collect information mainly around social, health and political aspects of life among individuals living in member states. They are usually conducted twice each year, in the spring and autumn, where each time approximately 1,000 individuals are randomly interviewed in each country. Satisfaction with life is a question frequently posed, based on the following four-scaled question: "On the whole, are you very satisfied, fairly satisfied, not very satisfied, or not at all satisfied with the life you lead?".

We examine two hypotheses relating to the sporting "feelgood" factor: (a) Better than expected national athletic performance increases happiness, (b) Hosting major sporting events increases happiness. As we know the characteristics of individuals interviewed, we are able to test our hypotheses for different subgroups of the data.

The events we study are staged at four year intervals, the summer Olympics and UEFA European Championships occurring in the same even-numbered years and the World Cup on the intervening even-numbered years. Because they are staged in the summer, between July and August, the only Eurobarometer questionnaires relevant are the ones performed in the autumn of each year; that is, the post-event surveys. ${ }^{9}$ Unfortunately, no such survey was conducted in the autumn of 1980. Moreover, the happiness question was not included in the autumn questionnaires of 1974, 1996, 1998, and 2002. Finally, the autumn 2004 Survey did not include the identification of the income level by individuals questioned. Hence, the years considered in our study for each sporting event are presented in Table 1.

Table 1: Data Period and Host

\begin{tabular}{|c|c|c|}
\hline Olympic Games & Euro Cup & World Cup \\
\hline 1976 (Canada) & 1976 (Yugoslavia) & 1978 (Argentina) \\
\hline 1984 (USA) & 1984 (France) & 1982 (Spain) \\
\hline 1988 (S. Korea) & 1988 (W. Germany) & 1986 (Mexico) \\
\hline 1992 (Spain) & 1992 (Sweden) & 1990 (Italy) \\
\hline 2000 (Australia) & 2000 (Belgium \& the Netherlands) & 1994 (USA) \\
\hline Periods Omitted: & $\begin{array}{r}\text { Olympics \& Euro Cup: 1980, 1996, } 2004 \\
\text { World Cup: 1974, 1998, } 2002\end{array}$ & \\
\hline
\end{tabular}

Notes: Bold figures represent Host Nations within the sample.

Spain hosted the World Cup in 1982, however the data for Spain is only available as of 1985.

If sporting success creates a "feelgood factor", we surely can not use the absolute medal count in the Olympics to measure success. For a country such as Luxembourg with a population of 480,000, winning a single Olympic gold medal may be considered a success; for Germany with a population of 82 million, it would represent a national

\footnotetext{
${ }^{7}$ On Germany the data prior to 1992 exists for West Germany. The available data for Greece starts in 1981, whereas for Spain and Portugal in 1985.

${ }^{8}$ Note that the reported happiness categories labeled under "Don’t Know" and "No Answer" are excluded.

${ }^{9}$ Although, given the available happiness data, the US was the host of the Games in 1984 and of the World Cup in 1994, we did not include US happiness data as this is collected annually in April- before the event.
} 
sporting crisis. Moreover, home nations typically perform to an above average level. ${ }^{10}$ To the extent that this is predictable, we expect people to discount this effect, but to the extent that the outperformance is unexpected it will also generate an increase in happiness.

Thus for the Olympics we focus on measures that relate expected national athletic performance, based on a simple model for predicting medal success, to actual performance. We hypothesise that any feelgood factor will be associated with deviations from expectations. ${ }^{11}$ Evidence from neuroscience supports this claim: “...the brain's dopamine currency seems to be tuned to the expectation of pleasure (or reward of some sort). Some of the brain's dopamine-producing nerve cells are programmed to monitor the difference between expected and actual reward...” (Siegfried, 2006; p.101).

To test the second hypothesis we include a dummy variable for the host. ${ }^{12}$ of course, our latter hypothesis might be rejected, as potential negative effects associated with hosting major sporting events exist; e.g. increased congestion, pollution and hooligan incidents.

For the case of international football championships we have a slightly simpler approach. ${ }^{13}$ There are a variety of ratings for national football teams that are maintained and updated on a match by match basis. If a national team does well in a championship then its rating will rise and we would expect this to create a feelgood factor. Likewise if the national team rating falls we would expect reported satisfaction levels to fall. Thus by comparing team ratings just before and after a championship we can proxy the potential of team performance in major competitions to affect the feelgood factor. For an outline of the methodology for predicting medals and obtaining Elo rankings see Appendix A.

Due to the ordinal nature of the happiness data, the model used for our estimations is an ordered Logit. Given the unobserved dependent variable $y_{i, t}^{*}=x_{i, t}^{\prime} \beta_{i}+\varepsilon_{i, t}$, representing true happiness levels, we observe

$$
\begin{aligned}
& y=0, \text { if } y^{*} \leq \kappa_{1} \\
& y=1, \text { if } \kappa_{1}<y^{*} \leq \kappa_{2} \\
& y=2, \text { if } \kappa_{2}<y^{*} \leq \kappa_{3}
\end{aligned}
$$

And so on, where $\kappa_{j}$ represent the threshold or cut-point parameters. The independent variables include the Sports Variables: medals/ranks and the host dummy; Macroeconomic Variables ${ }^{14}$ : GDP per capita, unemployment and inflation rates; Personal Controls: employment status, sex, age, age squared, marital status, household income quartiles and educational level reached. We also control for country, $s$, and year, $t$, effects. Our regressions are estimated over the event years only. That is, we estimate:

\footnotetext{
${ }^{10}$ For a detailed study on the determinants of the host effect for the Summer Olympic Games of 1928-1996 see Balmer et al. (2003); Host effect determinants for the Winter Olympics of 1908 till 1998 are studied in Balmer et al. (2001).

${ }^{11}$ This can be thought in terms of a set-point theory of happiness, where various aspects can create deviations from a predetermined level of happiness for a certain period of time (Easterlin, 2005).

${ }^{12}$ For the case of the Olympics note that we only have one host, Spain in 1992.

${ }^{13}$ Similar to the Olympics, studies on the determinants of soccer success use population and GDP variables, in addition to host, political and geographical indicators. See Hoffman et al. (2002), Houston and Wilson (2002), Hoffman et al. (2006), and Leeds and Leeds (2007).

${ }^{14}$ These are obtained from OECD’s Economic Outlook and Labour Force Statistics.
} 


$$
\text { Happiness }_{\text {ist }}=\text { aSport }_{s t}+\beta \text { MacroVar }_{s t}+\gamma \text { Personal }_{i s t}+c_{s}+y_{t}+v_{i s t}
$$

Where $u_{\text {ist }}$ is an i.i.d. error term.

Equation (1) is estimated under two specifications for the Sport Variables. For the Olympic variables we use the difference between actual and predicted medals; that is (Actual-Predicted). The model is then re-estimated using lagged actual medals as predictions for success in future Olympiads; that is (Actual-Actual Lagged). The former model can be considered as a rational expectations, whereas the latter as an adaptive expectations approach of Olympic performance. Finally, happiness is re-estimated excluding the only remaining boycott year within the sample, that of 1984, in order to avoid the distortion in medals caused by its inclusion. ${ }^{15}$

In the case of football events, our measure of performance is the difference between the post and pre tournament rankings; (RankPost-RankPre). We estimate the model only for countries which have qualified to participate. ${ }^{16}$

Finally, we perform a Difference-in-Difference (DiD) estimation. As mentioned in Section 3, Eurobarometer surveys are usually gathered twice each year, in the spring and in the autumn, with the sports event taking place in between. Thus, we can think of the treatment group as the group of individuals whose country hosted the event (Host) and the control group as the remaining non-host countries in that year. The variable After denotes the time period of the survey. The estimated coefficient of the dummy variable taking the value of unity for the countries that have hosted the event in the post-event time period only is the DiD estimator. That is, similar to (1), we estimate:

$$
\text { Happiness }_{\text {ist }}=\delta_{1} \text { Host }_{i s}+\delta_{2} \text { After }_{i t}+\delta_{3} \text { HostAfter }_{\text {ist }}+\beta \text { MacroVar }_{\text {st }}+\gamma \text { Personal }_{i s t}+c_{s}+y_{t}+v_{i s t}
$$

Since our data includes only one Olympic host, we apply this estimator only for the case of football over the years 1984, 1988, 1990 and 2000. These are the only years for which happiness data exists for both waves of the survey. For the years examined we have five hosting nations (see Table 1 in Section 3).

\section{Results}

Summary results of the happiness regressions on sports variables are reported in Table 2; Full results are reported in Appendix B. Models 1-4 focus on the Olympic Games. In more detail, Models 1 and 2 use the difference between our estimates of expected and actual medals (rational expectations), while models 3 and 4 use the difference between lagged and actual medals (adaptive expectations). Models 1 and 3 use all the years in our sample, while Models 2 and 4 excludes the only boycott affected Games for which happiness data is available, that is 1984.

The results from football tournaments based on the difference in ranking position are presented in Model 5. Finally, Model 6 presents the results of the DiD estimates for football events.

\footnotetext{
${ }^{15}$ We have checked for possible collinearity problems between our predictions and GDP per capita by evaluating the Variance Inflation Factor (VIF). Tolerance values and Condition Number were well below the suggested boundaries indicating no severe collinearity concerns between the variables in question [VIF=1.11, Tolerance $=0.901$, and Condition Number=7.824] (Greene, 2003).

${ }^{16}$ Nations that have not qualified to the tournament schedule friendly matches during the tournament period, and hence their ratings vary. We do not include a dummy for the winner of the soccer tournament as the Elo rating already incorporates the effect of the winner of each match on its rating- See Appendix A.
} 
In all tables, column 2 reports the estimated results using all observations, where each additional column reports the results for various subgroups; that is, for men, women, individuals aged below and above 50, in employment, with no higher education, in upper and lower income quartiles.

As far as the Olympics are concerned, we find that reported happiness is in general positively affected when performance is better than expected, but the effect is seldom significant. In fact, the difference between actual and expected medals is only significant for some subgroups when 1984 is excluded from the analysis (model 2), and then only for males, those aged under 50 and in higher income groups. However, when we use lagged medals to define expectations and exclude 1984 (model 4) the effect of outperformance is positive and significant for every group except males (for whom it is borderline). For the football competitions the ranking variable has the expected sign but is never significant. Overall we take this to provide some limited support for our first hypothesis- it is plausible that national success in sporting competitions can lead to an increased sense of satisfaction, but the effect is surely not a very powerful one.

Turning to the second hypothesis, the picture is more complicated. In all Olympics related models (1-4), hosting appears to have a negative impact on happiness, which is significant in a number of cases. As we have already observed in Section 3, this result is based on a single observation, Spain (Barcelona 1992), and might very well be capturing other events in Spain during that period. Moreover, it just might be the case that the Barcelona Games, while bringing joy to the Catalan minority in Spain, actually reduced satisfaction levels among the Castilian majority, especially since many Catalans used the event to promote Catalonia's independence from Spain (de Moragas et al., 1995). This possibility seems worthy of further study.

By contrast, the results for the FIFA World Cup and UEFA European Cup tournaments lend powerful support to hypothesis $2 .{ }^{17}$ The results of the model using differences in rankings (model 5) are broadly consistent with those of the DiD specification (model 6), which are only used to estimate the hosting effect. Hosting appears to be positively and significantly correlated with reported happiness for the population taken as a whole and for every subgroup in model 5, except for females.

The coefficients also give us some idea about the economic significance of these effects. For example, using the coefficients for all individuals (i.e. column 2, Model 5), hosting a soccer tournament increases happiness by $0.315 /(0.162+0.639)=0.4$ times the amount due to going from the second to the fourth income quartile, and $0.315 /(0.162+0.377)=0.6$ times the amount due to going from the second to the third income quartile. In a similar logic, happiness increases twice the amount of having a higher education $(0.315 / 0.163=2)$ and is as large as the satisfaction derived from being married $(0.315 / 0.287=1.098)$. Furthermore, it almost offsets the devastation of being divorced $(0.315 / 0.417=0.755)$ while the effect is one third the size of the impact of becoming unemployed $(0.315 / 0.942=0.334)$.

We now present some brief comments regarding the estimates for the personal controls. These are quite robust and in line with previous findings (see Oswald, 1997). Married individuals tend to be happier, whereas any other marital status leads to unhappiness. The latter include divorced, separated and widowed individuals. The sign

\footnotetext{
${ }^{17}$ Testing for the host effects of these two tournaments jointly provides us with more observations given the small number of major tournaments in our data.
} 
for those living as if married (defacto married) is insignificant for all groups other than those aged over 50, for whom the effect on reported happiness is negative. Happiness is U-shaped in relation to age and reported satisfaction levels of men are lower than those of women. Working status and income level variables are also in general significant. Being unemployed reduces happiness considerably, while the self-employed, students (School) and house-keepers (Home) tend to report higher levels of satisfaction. Belonging to a higher income quartile is associated with greater reported happiness. A similar statement can be made for the level of education- the higher the level of educational level reached the happier the individual appears to be. Finally, higher national income is associated with greater happiness levels while inflation and the unemployment rate are associated with lower levels of happiness; these results are in line with previous studies (see Di Tella et al. 2001, 2003). Marginal Effects are reported in Appendix C.

Based on some of the Eurobarometer questionnaires we managed to match household income quartiles- used in the regressions- to levels, in order to produce a rough estimate of the monetized value of the increase in happiness for the host country citizens. For example, when England hosted the Euro 96 tournament the average monthly income of households in the second quartile was $£ 870$ per month, while in the third quartile it was $£ 1575$ per month, a difference of $£ 705$. Sixty percent of this effect amounts to $£ 423$ per month. Given that there are approximately 20 million households in England, this amounts to a monthly "willingness to pay" in the region of £8 billion. Obviously this figure needs to be interpreted with caution, not least because of the Easterlin paradox: if everyone in the second income quartile were moved to the third, then those in the third to begin with would feel worse off. In any case, not everyone is in the second quartile, and hence the monetized value would differ by household.

Nonetheless, our results point to a substantial short term impact on measured happiness, suggesting that the feelgood factor from hosting events is a significant phenomenon.

Our rough valuation depends critically on the period over which the impact accrues. Given that the events take place in midsummer and the survey takes place in the autumn, the effect would appear to be sustained over a month or two. However, many advocates of bidding to host major events such as the Olympics claim that benefits can accrue both before and well after an event. For this reason we finally consider whether we could identify any effects on happiness in years before and after the event. The former we might consider "announcement effects", the latter "legacy effects". We thus generate four different Host dummy variables each of which takes the value of unity six, four, two and one years before the event takes place, respectively. To measure legacy effects we generate three different Host dummy variables each of which takes the value of unity one, two and four years following the event, respectively.

We run micro model regressions for each of the seven Host dummies presented above for the following combinations of sports events:

(a) Football events estimated jointly (3 World Cup (WC) and 7 European Championship (EC) Hosts)

(b) Olympic events (2 Hosts, including Athens 2004)

(c) All sporting events estimated together in order to gain from the richness of the available data (3 WC, 7 EC , 2 Olympics)

(d) WC events separately ( 3 of them), and

(e) EC events separately (7 of them) 
The results are reported in Appendix D. On (a) we find evidence of a significant negative impact of the host dummy 6 years before and 4 years before the event, across many subgroups of the population. Some evidence for a positive and significant effect is found for the 4 years following the event. On (b) there is no evidence of an anticipation effect, however we estimate a negative and significant impact of hosting the Olympics when using either the 2 or 4 year dummy following the event. Note that although the preevent dummy now contains information we have available for Greece in regards to the 2004 Athens Games, the post-event data contains only Spain, since our dataset ends in 2004. On (c) there is evidence across the majority of the population subcategories that the hosting dummy is negative and significant 6 years before the event. Finally, for European Championships (e) we find the hosting dummy is negative and significant 6 and 4 years before the event, but no evidence of any post event effects.

In all cases the estimation of the 1 year before and 1 year after the event dummies does not return any significant results in any subgroup of the population. Furthermore, in most estimations this is the case for the 2 year dummy as well. There is however one exception, that being the case of the WC (d). There all post event dummies are significant for the 2 and 4 years dummies for all subgroups. Also, the 1 year before and after the event dummies return positive happiness effects for the population as a whole, individuals under the age of 50, males, the unemployed and those who have not benefited from higher education.

Overall, these results do not generally support the view that there are systematically significant and positive anticipatory or legacy effects with respect to measured happiness, and if anything, there is some evidence that there are negative anticipatory effects, which might possibly be associated with difficulties often associated with the planning stages for such events. However, the pattern of results is not consistent, and in our view these results do not justify the inference that hosting events creates anything more than a short term feelgood factor. 
Table 2: Happiness Regressions - Summary Results

\begin{tabular}{|c|c|c|c|c|c|c|c|c|}
\hline Subgroup & $\begin{array}{l}\text { Whole } \\
\text { Sample }\end{array}$ & Aged $\geq 50$ & Aged $<50$ & Males & Females & Employed & $\begin{array}{l}\text { No Higher } \\
\text { Education }\end{array}$ & $\begin{array}{c}\text { In Upper } \\
\text { Income }\end{array}$ \\
\hline
\end{tabular}

Model 1: Olympic Games

\begin{tabular}{|c|c|c|c|c|c|c|c|c|c|}
\hline \multirow[t]{2}{*}{ (Actual-Predicted) } & 0.004 & -0.0001 & 0.006 & 0.008 & 0.00001 & 0.003 & 0.003 & 0.001 & 0.002 \\
\hline & $(0.008)$ & $(0.007)$ & $(0.009)$ & $(0.009)$ & $(0.007)$ & $(0.008)$ & $(0.007)$ & $(0.009)$ & $(0.007)$ \\
\hline \multirow{2}{*}{ Host } & -0.117 & 0.023 & -0.198 & $-0.226^{* *}$ & -0.022 & -0.106 & -0.029 & $-0.334 * * *$ & 0.122 \\
\hline & $(0.108)$ & $(0.106)$ & $(0.128)$ & $(0.10)$ & $(0.119)$ & $(0.109)$ & $(0.111)$ & $(0.10)$ & $(0.126)$ \\
\hline Number of Obs. & 43,607 & 16,464 & 27,143 & 21,487 & 22,120 & 41,468 & 33,602 & 19,995 & 23,612 \\
\hline Pseudo- $\mathrm{R}^{2}$ & 0.0831 & 0.0817 & 0.0878 & 0.0807 & 0.0879 & 0.0797 & 0.0749 & 0.0873 & 0.0756 \\
\hline \multicolumn{10}{|c|}{ Model 2: Olympic Games Excluding 1984} \\
\hline \multirow[t]{2}{*}{ (Actual-Predicted) } & 0.012 & 0.003 & 0.019* & $0.017^{*}$ & 0.008 & 0.011 & 0.012 & $0.017 *$ & 0.009 \\
\hline & $(0.009)$ & $(0.009)$ & $(0.01)$ & $(0.009)$ & $(0.009)$ & $(0.009)$ & $(0.009)$ & $(0.01)$ & $(0.009)$ \\
\hline \multirow[t]{2}{*}{ Host } & -0.131 & 0.014 & -0.213 & $-0.259 * *$ & -0.02 & -0.122 & -0.04 & $-0.344 * * *$ & 0.113 \\
\hline & $(0.125)$ & $(0.109)$ & $(0.153)$ & $(0.12)$ & $(0.13)$ & $(0.125)$ & $(0.123)$ & $(0.114)$ & $(0.138)$ \\
\hline Number of Obs. & 35,766 & 13,601 & 22,165 & 17,653 & 18,113 & 34,121 & 27,226 & 15,995 & 19,771 \\
\hline Pseudo- $\mathrm{R}^{2}$ & 0.0811 & 0.0804 & 0.086 & 0.0799 & 0.0853 & 0.077 & 0.0714 & 0.0871 & 0.0732 \\
\hline
\end{tabular}

Model 3: Olympic Games

\begin{tabular}{|c|c|c|c|c|c|c|c|c|c|}
\hline (Actual-Actual Lagged) & $\begin{array}{c}0.001 \\
(0.005)\end{array}$ & $\begin{array}{c}0.005 \\
(0.005)\end{array}$ & $\begin{array}{l}-0.001 \\
(0.005)\end{array}$ & $\begin{array}{l}0.0002 \\
(0.005)\end{array}$ & $\begin{array}{c}0.003 \\
(0.005)\end{array}$ & $\begin{array}{c}0.001 \\
(0.005)\end{array}$ & $\begin{array}{c}0.002 \\
(0.005)\end{array}$ & $\begin{array}{c}0.001 \\
(0.004)\end{array}$ & $\begin{array}{c}0.002 \\
(0.005)\end{array}$ \\
\hline Host & $\begin{array}{l}-0.156 \\
(0.123)\end{array}$ & $\begin{array}{l}-0.087 \\
(0.129)\end{array}$ & $\begin{array}{l}-0.187 \\
(0.129)\end{array}$ & $\begin{array}{l}-0.22^{*} \\
(0.114)\end{array}$ & $\begin{array}{l}-0.101 \\
(0.144)\end{array}$ & $\begin{array}{l}-0.147 \\
(0.123)\end{array}$ & $\begin{array}{l}-0.085 \\
(0.131) \\
\end{array}$ & $\begin{array}{c}-0.359 * * * \\
(0.112)\end{array}$ & $\begin{array}{c}0.065 \\
(0.148) \\
\end{array}$ \\
\hline $\begin{array}{l}\text { Number of Obs. } \\
\text { Pseudo- } \mathrm{R}^{2}\end{array}$ & $\begin{array}{l}44,440 \\
0.0825\end{array}$ & $\begin{array}{l}16,806 \\
0.0812\end{array}$ & $\begin{array}{l}27,634 \\
0.0872\end{array}$ & $\begin{array}{c}21,893 \\
0.080\end{array}$ & $\begin{array}{l}22,547 \\
0.0873\end{array}$ & $\begin{array}{l}42,286 \\
0.0791\end{array}$ & $\begin{array}{l}34,251 \\
0.0744\end{array}$ & $\begin{array}{l}20,472 \\
0.0864\end{array}$ & $\begin{array}{r}23,968 \\
0.075\end{array}$ \\
\hline \multicolumn{10}{|c|}{ Model 4: Olympic Games Excluding 1984} \\
\hline (Actual-Actual Lagged) & $\begin{array}{l}0.009 * * \\
(0.004)\end{array}$ & $\begin{array}{l}0.008^{* *} \\
(0.004)\end{array}$ & $\begin{array}{c}0.009 * \\
(0.005)\end{array}$ & $\begin{array}{c}0.008 \\
(0.005)\end{array}$ & $\begin{array}{c}0.009 \text { *** } \\
(0.004)\end{array}$ & $\begin{array}{l}0.008^{* *} \\
(0.004)\end{array}$ & $\begin{array}{l}0.009 * * \\
(0.004)\end{array}$ & $\begin{array}{l}0.008^{*} \\
(0.004)\end{array}$ & $\begin{array}{r}0.01^{* *} \\
(0.004)\end{array}$ \\
\hline Host & $\begin{array}{l}-0.264^{*} \\
(0.137)\end{array}$ & $\begin{array}{l}-0.135 \\
(0.124)\end{array}$ & $\begin{array}{c}-0.336^{* *} \\
(0.159)\end{array}$ & $\begin{array}{c}-0.351^{* *} \\
(0.141)\end{array}$ & $\begin{array}{c}-0.188 \\
(0.14)\end{array}$ & $\begin{array}{l}-0.25^{*} \\
(0.135)\end{array}$ & $\begin{array}{l}-0.181 \\
(0.136)\end{array}$ & $\begin{array}{c}-0.461^{* * *} \\
(0.13)\end{array}$ & $\begin{array}{l}-0.05 \\
(0.152)\end{array}$ \\
\hline Number of Obs. & 36,599 & 13,943 & 22,656 & 18,059 & 18,540 & 34,939 & 27,875 & 16,472 & 20,127 \\
\hline Pseudo-R ${ }^{2}$ & 0.0808 & 0.0801 & 0.0855 & 0.0793 & 0.0851 & 0.0766 & 0.0714 & 0.0861 & 0.073 \\
\hline
\end{tabular}

Model 5: World \& Euro Cup - Difference in Ranking Position and Host

\begin{tabular}{lcccccccccc}
\hline RankPost-RankPre) & 0.017 & 0.012 & 0.021 & 0.017 & 0.016 & 0.017 & 0.013 & 0.017 & 0.017 \\
& $(0.011)$ & $(0.009)$ & $(0.013)$ & $(0.012)$ & $(0.011)$ & $(0.011)$ & $(0.011)$ & $(0.011)$ & $(0.012)$ \\
Host & $\mathbf{0 . 3 1 5 * *}$ & $\mathbf{0 . 4 1 5 * *}$ & $\mathbf{0 . 2 5 8} *$ & $\mathbf{0 . 4 0}^{* * *}$ & 0.245 & $\mathbf{0 . 2 9 8}^{*}$ & $\mathbf{0 . 3 4 8}^{* *}$ & $\mathbf{0 . 2 9 5}^{* *}$ & $\mathbf{0 . 3 1 1}^{*}$ \\
& $\mathbf{( 0 . 1 5 2 )}$ & $\mathbf{( 0 . 1 6 2 )}$ & $\mathbf{( 0 . 1 4 9 )}$ & $\mathbf{( 0 . 1 4 8 )}$ & $(0.16)$ & $\mathbf{( 0 . 1 5 2 )}$ & $\mathbf{( 0 . 1 5 8 )}$ & $\mathbf{( 0 . 1 4 3 )}$ & $\mathbf{( 0 . 1 6 2 )}$ \\
\hline Number of Obs. & 45,807 & 17,194 & 28,613 & 22,343 & 23,464 & 43,240 & 35,368 & 20,810 & 24,997 \\
Pseudo-R ${ }^{2}$ & 0.0849 & 0.0834 & 0.0903 & 0.0817 & 0.0907 & 0.0797 & 0.0773 & 0.087 & 0.0751
\end{tabular}

Model 6: World and Euro Cup - DiD

\begin{tabular}{|c|c|c|c|c|c|c|c|c|c|}
\hline Host Post-Event & $\begin{array}{c}0.366^{* * *} \\
(0.11)\end{array}$ & $\begin{array}{l}0.40^{* * *} \\
(0.128)\end{array}$ & $\begin{array}{c}0.35^{* * *} \\
(0.102)\end{array}$ & $\begin{array}{c}0.335^{* * *} \\
(0.112)\end{array}$ & $\begin{array}{c}0.406^{* * *} \\
(0.126)\end{array}$ & $\begin{array}{c}0.354^{* * *} \\
(0.117)\end{array}$ & $\begin{array}{c}0.352^{* * *} \\
(0.117)\end{array}$ & $\begin{array}{c}0.321^{* *} \\
(0.139)\end{array}$ & $\begin{array}{c}0.383^{* * *} \\
(0.082)\end{array}$ \\
\hline Number of Obs. & 67,476 & 24,977 & 42,499 & 32,892 & 34,584 & 63,749 & 52,170 & 29,575 & 37,901 \\
\hline Pseudo- $\mathrm{R}^{2}$ & 0.0819 & 0.0826 & 0.0851 & 0.0793 & 0.0865 & 0.0777 & 0.0737 & 0.0858 & 0.0717 \\
\hline
\end{tabular}

Notes: Regressions are Ordered Logits. The dependent variable is ‘self-reported satisfaction'.

$*, * *$ and $* * *$ indicate significance at the $10 \%, 5 \%$ and $1 \%$ level. Clustered standard errors are reported in parenthesis. 


\section{Concluding Remarks}

In this paper we use Eurobarometer survey data to test two hypotheses concerning the "feelgood factor" which is often claimed to be associated with major sporting events:

1. Better than expected national athletic performance raises happiness

2. Hosting major sporting events raises reported happiness

We find some limited support for the first hypothesis, but the results are seldom statistically significant and the effects may be considered nugatory. We do, however, find significant support for the second effect when it comes to hosting major football championships. It should be noted that these results derive from a sample of European nations where football is the dominant sport; in regions of the world where football is not dominant one might obtain different results. Our findings suggest a significant and positive short term feelgood effect, but we find little systematic evidence for longer term benefits, either before or after the event. In addition, although we find the magnitude of hosting football events in comparison to a person being married, say, is large, the former effect seems very short-lived, while the latter effect is generally much longer lasting.

We believe that our results make sense of the peculiar economics of major sports events. Politicians responsible for bidding to host events consistently claim that these generate substantial long term economic benefits, and yet there is ample evidence in the sports economics literature showing that this is not the case. Research has shown that there are neither significant increases in tourism, nor in full-time employment levels, nor regional economic growth arising from hosting events. And yet the public does not appear to penalize politicians through the ballot box for their erroneous claims; indeed most politicians calculate that hosting events can only enhance their political standing. This makes sense if the benefits of hosting are not derived through economic gains, but through the feelgood factor, specifically associated with being the host.

With the existence of ample happiness data, it is interesting to see whether similar or other sporting events have a significant, and even potentially lasting, impact on individual happiness.

\section{Acknowledgements}

The authors are indebted to Robert MacCulloch and Andrew Oswald for valuable comments and suggestions in earlier drafts of this study. We further wish to thank Dennis Coates, Adam Golinski, Pantelis Koutroumpis, Stephanie Leach, seminar participants at the Norwegian School of Economics and Business Administration, participants of the Transatlantic Conference and European Doctoral Research Conference held at London Business School and Tanaka Business School, respectively, for providing valuable feedback in earlier drafts of this paper. Finally, we thank the UK Data Archive for provision of the Eurobarometer Data. 


\section{Appendix A: Olympic and Football Success Estimation Methodology}

Medal tables have attracted a small econometric industry of their own. The leading article by Grimes et al. (1974) uses a simple model with population, per capita GNP and a political regime binary variable to test the superiority of communist countries in winning medals for the Munich 1972 Olympic Games. All variables were estimated to be significantly positive, meaning that the wealth of nations matter for Olympic success.

All of the more recent studies are along the same lines, incorporating population, GDP (or GNP) in levels or per capita terms, host and political regime variables (for a panel analysis of success at the Summer Olympics see Johnson and Ali (2000) and Bernard and Busse (2004)). Further studies use different methodologies or additional variables, such as geographical indicators. Tcha and Pershin (2003) use the theory of revealed comparative advantage; Johnson and Ali (2004) examine the determinants of the Winter Olympics; Hoffmann et al. (2002, 2004) study the Sydney 2000 Games, also studied by Moosa and Smith (2004) using an extreme bound analysis; Roberts (2006) uses Poisson and negative binomial regression models for the Athens 2004 Olympics. Additional papers include Kuper and Sterken (2001) and Rathke and Woitek (2007).

Even though all studies agree on the explanatory power of the above mentioned independent variables, these are by no means the only determinants of success. Quite importantly, we should note that success may not only be an exogenous factor determined by income and population models. Endogenous issues arise when the rating of sport performance is based on subjective judgments (e.g. in gymnastics). ${ }^{18}$

To derive expectations of the number of Olympic medals won by the nations in our sample, we adopt the data and methodology of Bernard and Busse (2004), which we briefly outline here. Their model uses annual data on GDP and population levels to explain the number of medals won in the Summer Olympics, for 211 participating countries over the period 1960-1996, inclusive. The model can then be used to generate a prediction for each Olympic year, which is assumed to be the rational expectation for each nation's medal count. Our sample is being divided in six sub-samples in order to estimate each Olympic year's expected medal count (e.g. to predict medals won in 1976 we estimate the model using data between 1960-1972).

However, in predicting medals we have to account for some anomalies arising from political interference. Notably, several governments boycotted the 1976, 1980, 1984, and 1988 Olympics, but the ones of the Moscow 1980 and Los Angeles 1984 Olympics are arguably considered as the two major ones. In the former the US and West Germany refused to participate, which in turn led to the Soviet Union's and East Germany's boycott of the 1984 Games. None of these four countries has been ranked below $10^{\text {th }}$ place since 1960, with the US and the Soviet Union usually battling for first place. The boycotts bias the estimation of expectations of medals gained, as participating nations substantially out-performed in 1980 and 1984. As an example consider the number of total medals won by the US and the Soviet Union in the summer Olympics over the period 1976-1988 (see Table A1). The distortion is clearly visible. Both the US and the Soviets outperform by a factor of around 70 medals when the other boycotts the Games.

\footnotetext{
${ }^{18}$ For an analysis on performance judgments see Damisch et al. (2006).
} 
Table A1: US and Soviet Union Medal Totals (1976-1988)

\begin{tabular}{lcc}
\hline & US & Soviet Union \\
\cline { 2 - 3 } $\mathbf{1 9 7 6}$ & 94 & 125 \\
$\mathbf{1 9 8 0}$ & Boycotted & 195 \\
$\mathbf{1 9 8 4}$ & 174 & Boycotted \\
$\mathbf{1 9 8 8}$ & 94 & 132 \\
\hline
\end{tabular}

Source: International Olympic Committee website (www.olympic.org)

We assume that individuals rationally anticipate the effects of boycotts on medal shares and adjust their expectations accordingly. For example, we assume that when forming expectations for 1984, medals won in 1980 are discounted. Similarly, in forming expectations for 1988, the results from 1980 and 1984 are discounted. Hence, truncation of the sample used for the predictions is shown in Table A2.

Table A2: Sample Truncation

\begin{tabular}{lc}
\hline Period & Estimate Medals for: \\
\hline $1960-1972$ & 1976 \\
$1960-1976$ & 1984 \\
$1960-1976$ & 1988 \\
$1960-1988$ (Excluding 1980, 1984) & 1992 \\
1960-1996 (Excluding 1980, 1984) & 2000 \\
\hline
\end{tabular}

Due to the increasing number of sports added in the Olympic agenda the dependent variable used in the analysis is medal shares (MedShr), as this represents a standardized measure of success. The explanatory variables are the log of population $(\ln P O P)$ and the log of GDP per capita (lnGDPcap). The model estimated using a Tobit (Tobin, 1958) pooled over the Olympic years for 211 countries. Three dummy variables capturing a 'Soviet control' of the country, existence of a 'planned regime', and a 'host' effect, in addition to the lagged Medal Share $\left(M e d S h r_{t-1}\right)$ are also included. ${ }^{19}$ For the case of the 1984 and 1988 Olympics the lagged Medals Share is the value obtained on the Games of 1976, since the boycott years are excluded from the estimation procedure. For countries participating in 1960, the lagged medal share achieved during the 1956 Games is added, adding more observations to our estimation. The pooled Tobit model to be estimated is, thus, of the following form: $\operatorname{MedSh} r_{i, t}=\left\{\begin{array}{lr}b_{1} \ln \text { POP }_{i, t}+b_{2} \ln \operatorname{GDPcap}_{i, t}+b_{3} \text { MedShr }_{i, t-1}+\text { Host }_{i, t}+\text { Planned }_{i, t}+\text { Soviet }_{i, t}+\sum_{t=1960}^{\sum_{\text {subsample }} D_{t}+\varepsilon_{i, t},} & \text { if MedShr } r_{i, t}^{*} \geq 0 \\ 0, & \text { if MedShr } r_{i, t}^{*}<0\end{array}\right.$

Where, $D_{t}$ are year dummies (in four year intervals), and $\varepsilon_{i, t}$ are the idiosyncratic disturbances. Note that as we wish to estimate the predicted medals for each sub sample separately, the factor $D_{t}$ will vary according to our data truncation.

\footnotetext{
19 The lagged medal share represents the 'durability' on the production of Olympic athletes (see Bernard and Busse, 2004).
} 
We report the estimated results in Table A3. Given these, predicted medals are calculated using per capita GDP and population figures of the year preceding a given Olympiad. $^{20}$

Table A3: Panel Tobit, Estimated Coefficients used for Predictions

\begin{tabular}{|c|c|c|c|c|}
\hline Independent & \multicolumn{4}{|c|}{ Coefficients } \\
\hline & 1960-1972 & $1960-1976$ & 1960-1988 & 1960-1996 \\
\hline Log Population & $\begin{array}{c}0.003^{* * *} \\
(0.0006)\end{array}$ & $\begin{array}{c}0.0026^{* * *} \\
(0.0005)\end{array}$ & $\begin{array}{c}0.0025^{* * *} \\
(0.0004)\end{array}$ & $\begin{array}{c}0.0027^{* * *} \\
(0.0003)\end{array}$ \\
\hline Log GDP p.c. & $\begin{array}{c}0.0019 * * * \\
(0.0006)\end{array}$ & $\begin{array}{c}0.0018^{* * *} \\
(0.0006)\end{array}$ & $\begin{array}{c}0.002^{* * *} \\
(0.0005)\end{array}$ & $\begin{array}{c}0.0024^{* * *} \\
(0.0004)\end{array}$ \\
\hline Medal Share $t$ ed & $\begin{array}{c}0.8791^{* * *} \\
(0.052)\end{array}$ & $\begin{array}{c}0.9139 * * * \\
(0.0493)\end{array}$ & $\begin{array}{c}0.8937 * * * \\
(0.0403)\end{array}$ & $\begin{array}{c}0.8644 * * * \\
(0.0375)\end{array}$ \\
\hline Host & $\begin{array}{c}0.0213 \text { *** } \\
(0.0029)\end{array}$ & $\begin{array}{c}0.0196 * * * \\
(0.0027)\end{array}$ & $\begin{array}{c}0.0227 * * * \\
(0.0037)\end{array}$ & $\begin{array}{c}0.0187^{* * *} \\
(0.0041)\end{array}$ \\
\hline Planned & $\begin{array}{c}0.0042 \\
(0.0029)\end{array}$ & $\begin{array}{c}0.0052^{* *} \\
(0.0022)\end{array}$ & $\begin{array}{c}0.0063^{* * *} \\
(0.0018)\end{array}$ & $\begin{array}{c}0.0073^{* * *} \\
(0.0026)\end{array}$ \\
\hline Soviet & $\begin{array}{c}0.0134^{* * *} \\
(0.0037) \\
\end{array}$ & $\begin{array}{c}0.0142^{* * *} \\
(0.0033) \\
\end{array}$ & $\begin{array}{c}0.0131^{* * *} \\
(0.003)\end{array}$ & $\begin{array}{l}0.014^{* * *} \\
(0.0028)\end{array}$ \\
\hline $\begin{array}{l}\text { Year Dummies } \\
\text { Log Likelihood } \\
\text { Obs }\end{array}$ & $\begin{array}{c}\text { YES } \\
470.074 \\
344\end{array}$ & $\begin{array}{c}\text { YES } \\
580.426 \\
430\end{array}$ & $\begin{array}{c}\text { YES } \\
723.21 \\
553\end{array}$ & $\begin{array}{c}\text { YES } \\
1087.458 \\
881\end{array}$ \\
\hline
\end{tabular}

In regards to a measure of success for national football teams, the use of the official FIFA-Coca Cola rankings is inadequate as these were first introduced in 1993. The best alternative ranking covering the time span of this study is the Elo Ratings. This rating is calculated and adjusted after each single match a national team plays at any level of competition using the formula: $R_{\text {Post }}=R_{\text {Pre }}+k\left(W-W_{\text {exp }}\right)$, where $R_{\text {Post }}$ and $R_{\text {Pre }}$ are the post and pre event ratings respectively; $k$ is a weight factor according to the type of match (whether a World Cup match, a friendly, etc) which is further adjusted to account for the goal difference in the game; $W$ represents the result of the game ( 1 for a victory, 0.5 for a draw, and 0 if the team loses); and $W_{\text {exp }}$ represents a win expectancy given by $W_{\text {exp }}=\frac{1}{10^{-d r / 400}+1}$. In the last expression, $d r$ represents the difference in ratings between the two teams, where an extra 100 points are added to the home team. ${ }^{21}$

Thus, the Elo Ratings include expectations based on the historical performance of the national team on the pitch. Instead of using this as a measure of expectations of tournament ranking (for which we have no natural metric), we compare expected Elo rankings with the Elo ranking after the tournament has occurred. This allows us to test for the significance of any deviations from the pre-event ranks, where we hypothesize that positive deviations engender a feelgood factor, and vice and versa. ${ }^{22}$

\footnotetext{
${ }^{20}$ Growth rates of GDP per capita and population figures for the remaining years were gathered by the OECD Factbooks and UN Statistical Yearbooks. The Soviet and Planned dummy variables are not used in the medal predictions, since this is a study of OECD nations.

${ }^{21}$ For further details see www.eloratings.net .

22 Note that although a larger medal share is desirable for the Olympics, a lower Elo ranking (i.e. closer to one) is better. To avoid confusion in interpreting coefficients we reverse the sign of the latter variable.
} 
Appendix B: Full Specification of the regressions

\section{Model 1: Olympic Games}

\begin{tabular}{|c|c|c|c|c|c|c|c|c|c|}
\hline Subgroup & None & Aged $\geq 50$ & Aged $<50$ & Males & Females & Employed & $\begin{array}{l}\text { No Higher } \\
\text { Education }\end{array}$ & $\begin{array}{c}\text { In Upper } \\
\text { Income }\end{array}$ & $\begin{array}{c}\text { Not in } \\
\text { Upper Inc. }\end{array}$ \\
\hline \multicolumn{10}{|l|}{ Sport Variables } \\
\hline \multirow[t]{2}{*}{ (Actual-Predicted) } & 0.005 & 0.001 & 0.008 & 0.01 & 0.001 & 0.004 & 0.005 & 0.007 & 0.003 \\
\hline & $(0.008)$ & $(0.007)$ & $(0.009)$ & $(0.009)$ & $(0.007)$ & $(0.008)$ & $(0.008)$ & $(0.009)$ & $(0.008)$ \\
\hline \multirow[t]{2}{*}{ Host } & -0.119 & 0.02 & -0.199 & $-0.227^{* *}$ & -0.024 & -0.109 & -0.031 & $-0.334 * * *$ & 0.118 \\
\hline & $(0.109)$ & $(0.105)$ & $(0.13)$ & $(0.101)$ & $(0.121)$ & $(0.11)$ & (0.113) & $(0.10)$ & $(0.127)$ \\
\hline \multicolumn{10}{|l|}{ Macro Variables } \\
\hline \multirow[t]{2}{*}{ GDP p.c. } & 0.00001 & 0.00001 & 0.00002 & 0.00002 & 0.00001 & 0.00001 & 0.00001 & 0.00001 & 0.00001 \\
\hline & $(0.00001)$ & $(0.00002)$ & $(0.00002)$ & $(0.00002)$ & $(0.00001)$ & $(0.00001)$ & $(0.00001)$ & $(0.00002)$ & $(0.00002)$ \\
\hline \multirow[t]{2}{*}{ Unemployment } & $-3.383^{*}$ & $-4.494 * *$ & -2.847 & -2.56 & $-4.098^{* *}$ & $-3.196 *$ & $-4.23^{* *}$ & -2.427 & $-3.943^{* *}$ \\
\hline & (1.891) & $(1.958)$ & (2.094) & $(1.98)$ & (1.853) & (1.889) & (1.965) & $(2.235)$ & $(1.876)$ \\
\hline \multirow[t]{2}{*}{ Inflation } & -2.488 & -1.922 & -2.989 & -2.086 & -2.869 & -2.517 & -2.181 & -2.266 & -2.515 \\
\hline & $(2.086)$ & $(1.878)$ & $(2.342)$ & $(2.263)$ & $(1.961)$ & $(2.065)$ & $(2.087)$ & $(1.984)$ & $(2.515)$ \\
\hline \multicolumn{10}{|l|}{ Personal Controls } \\
\hline \multirow[t]{2}{*}{ Unemployed } & $-0.916^{* * *}$ & $-0.742^{* * *}$ & $-1.004^{* * *}$ & $-1.155^{* * *}$ & $-0.696^{* * *}$ & & $-0.964 * * *$ & $-0.686^{* * *}$ & $-1.009 * * *$ \\
\hline & $(0.083)$ & $(0.118)$ & $(0.087)$ & $(0.099)$ & $(0.095)$ & & $(0.085)$ & $(0.117)$ & $(0.08)$ \\
\hline \multirow[t]{2}{*}{ Self employed } & $0.081^{* *}$ & 0.07 & $0.086^{*}$ & 0.06 & $0.106^{*}$ & $0.081 *$ & 0.058 & $0.106^{* *}$ & 0.032 \\
\hline & $(0.041)$ & $(0.067)$ & $(0.048)$ & $(0.046)$ & $(0.06)$ & $(0.041)$ & $(0.049)$ & $(0.042)$ & $(0.07)$ \\
\hline \multirow[t]{2}{*}{ Male } & $-0.087 * * *$ & 0.011 & $-0.136^{* * *}$ & & & $-0.06^{* *}$ & $-0.075^{* *}$ & $-0.096^{* *}$ & $-0.069 *$ \\
\hline & $(0.031)$ & $(0.043)$ & $(0.035)$ & & & $(0.029)$ & $(0.031)$ & $(0.047)$ & $(0.037)$ \\
\hline \multirow[t]{2}{*}{ Married } & $0.245^{* * *}$ & 0.114 & $0.328^{* * *}$ & $0.181^{* * *}$ & $0.289 * * *$ & $0.235^{* * *}$ & $0.217^{* * *}$ & $0.252^{* * *}$ & $0.245^{* * *}$ \\
\hline & $(0.037)$ & $(0.087)$ & $(0.041)$ & $(0.05)$ & $(0.049)$ & $(0.038)$ & $(0.046)$ & $(0.044)$ & $(0.05)$ \\
\hline \multirow[t]{2}{*}{ Defacto Married } & 0.018 & $-0.229 *$ & 0.087 & -0.043 & 0.072 & 0.027 & -0.011 & 0.019 & 0.007 \\
\hline & $(0.057)$ & $(0.122)$ & $(0.062)$ & $(0.076)$ & $(0.068)$ & $(0.058)$ & $(0.072)$ & $(0.078)$ & $(0.082)$ \\
\hline \multirow[t]{2}{*}{ Divorced } & $-0.296^{* * *}$ & $-0.361 * * *$ & $-0.245^{* * *}$ & $-0.217^{* *}$ & $-0.344 * * *$ & $-0.284 * * *$ & $-0.372^{* * *}$ & -0.121 & $-0.331^{* * *}$ \\
\hline & $(0.077)$ & $(0.119)$ & $(0.087)$ & $(0.099)$ & $(0.101)$ & $(0.081)$ & $(0.087)$ & $(0.122)$ & $(0.077)$ \\
\hline \multirow[t]{2}{*}{ Separated } & $-0.413^{* * *}$ & $-0.658^{* * *}$ & $-0.285^{* *}$ & -0.068 & $-0.58^{* * *}$ & $-0.397^{* * *}$ & $-0.537 * * *$ & -0.134 & $-0.493^{* * *}$ \\
\hline & $(0.11)$ & $(0.211)$ & $(0.138)$ & $(0.207)$ & $(0.111)$ & $(0.114)$ & $(0.133)$ & $(0.204)$ & $(0.126)$ \\
\hline \multirow[t]{2}{*}{ Widowed } & $-0.235^{* * *}$ & $-0.272^{* * *}$ & $-0.263^{*}$ & $-0.376^{* * *}$ & $-0.113^{\prime}$ & $-0.242^{* * *}$ & $-0.264^{* * *}$ & -0.168 & $-0.235^{* * *}$ \\
\hline & $(0.054)$ & $(0.088)$ & $(0.143)$ & $(0.094)$ & $(0.065)$ & $(0.055)$ & $(0.06)$ & $(0.108)$ & $(0.059)$ \\
\hline Second Income Quar. & $0.165^{* * *}$ & $0.117^{* *}$ & $0.191^{* * *}$ & $0.171^{* * *}$ & $0.139 * * *$ & $0.154^{* * *}$ & $0.169 * * *$ & & $0.171^{* * *}$ \\
\hline & $(0.038)$ & $(0.048)$ & $(0.047)$ & $(0.043)$ & $(0.05)$ & $(0.038)$ & $(0.04)$ & & $(0.04)$ \\
\hline Third Income Quar. & $0.321^{* * *}$ & $0.249 * * *$ & $0.354 * * *$ & $0.305^{* * *}$ & $0.317^{* * *}$ & $0.303^{* * *}$ & $0.316^{* * *}$ & $-0.278^{* * *}$ & \\
\hline & $(0.045)$ & $(0.064)$ & $(0.046)$ & $(0.055)$ & $(0.052)$ & $(0.046)$ & $(0.049)$ & $(0.033)$ & \\
\hline Fourth Income Quar. & $0.573^{* * *}$ & $0.573^{* * *}$ & $0.589 * * *$ & $0.55^{* * *}$ & $0.586^{* * *}$ & $0.555^{* * *}$ & $0.566^{* * *}$ & & \\
\hline & $(0.045)$ & $(0.068)$ & $(0.047)$ & (0.049) & $(0.054)$ & $(0.045)$ & $(0.052)$ & & \\
\hline Age & $-0.052 * * *$ & 0.044 & $-0.088^{* * *}$ & $-0.055^{* * *}$ & $-0.048^{* * *}$ & $-0.049 * * *$ & $-0.051^{* * *}$ & $-0.055^{* * *}$ & $-0.049^{* * *}$ \\
\hline & $(0.005)$ & $(0.03)$ & $(0.011)$ & $(0.007)$ & $(0.006)$ & $(0.005)$ & $(0.005)$ & $(0.009)$ & $(0.006)$ \\
\hline $\mathrm{Age}^{2}$ & $0.001^{* * *}$ & -0.0002 & $0.001^{* * *}$ & $0.001 * * *$ & $0.001^{* * *}$ & $0.001^{* * *}$ & $0.001^{* * *}$ & $0.001 * * *$ & $0.001^{* * *}$ \\
\hline & $(0.0001)$ & $(0.0002)$ & $(0.0002)$ & $(0.0001)$ & $(0.0001)$ & $(0.0001)$ & $(0.0001)$ & $(0.0001)$ & $(0.0001)$ \\
\hline Lower Education & 0.013 & 0.068 & 0.033 & 0.009 & 0.017 & 0.014 & 0.02 & 0.043 & -0.003 \\
\hline & $(0.049)$ & $(0.069)$ & $(0.057)$ & (0.051) & $(0.059)$ & $(0.05)$ & $(0.046)$ & (0.058) & $(0.057)$ \\
\hline Secondary Education & 0.037 & $0.174^{* *}$ & 0.019 & 0.061 & 0.007 & 0.051 & 0.044 & 0.073 & 0.052 \\
\hline & $(0.051)$ & $(0.086)$ & $(0.056)$ & $(0.064)$ & $(0.06)$ & $(0.051)$ & $(0.048)$ & $(0.062)$ & $(0.063)$ \\
\hline Higher Education & $0.209 * * *$ & $0.279 * * *$ & $0.214 * * *$ & $0.233^{* * *}$ & $0.192 * * *$ & $0.209 * * *$ & & $0.229 * * *$ & $0.222^{* * *}$ \\
\hline & $(0.052)$ & $(0.088)$ & $(0.06)$ & $(0.058)$ & $(0.06)$ & $(0.053)$ & & $(0.054)$ & $(0.072)$ \\
\hline Retired & 0.066 & $0.077^{\prime}$ & $-0.369 *$ & 0.049 & 0.027 & 0.077 & 0.069 & $0.15^{*}$ & -0.006 \\
\hline & $(0.05)$ & $(0.065)$ & $(0.214)$ & $(0.076)$ & $(0.055)$ & $(0.05)$ & $(0.051)$ & $(0.078)$ & $(0.059)$ \\
\hline Home & 0.058 & 0.056 & 0.067 & 0.12 & 0.044 & $0.075^{*}$ & 0.058 & $0.175^{* * *}$ & -0.033 \\
\hline & $(0.042)$ & (0.058) & $(0.047)$ & $(0.186)$ & $(0.041)$ & $(0.042)$ & $(0.047)$ & $(0.053)$ & $(0.055)$ \\
\hline School & $0.194 * * *$ & $-0.347 *$ & $0.153^{* *}$ & $0.196^{* *}$ & $0.195^{* * *}$ & $0.20^{* * *}$ & $0.156^{* *}$ & 0.087 & $0.264^{* * *}$ \\
\hline & $(0.061)$ & $(0.191)$ & $(0.062)$ & $(0.083)$ & $(0.072)$ & $(0.064)$ & $(0.065)$ & $(0.082)$ & $(0.078)$ \\
\hline Observations & 43,607 & 16,464 & 27,143 & 21,487 & 22,120 & 41,468 & 33,602 & 19,995 & 23,612 \\
\hline Pseudo-R2 & 0.0831 & 0.0817 & 0.0879 & 0.0807 & 0.0879 & 0.0797 & 0.0749 & 0.0873 & 0.0756 \\
\hline Year Effects & Yes & Yes & Yes & Yes & Yes & Yes & Yes & Yes & Yes \\
\hline Country Effects & Yes & Yes & Yes & Yes & Yes & Yes & Yes & Yes & Yes \\
\hline
\end{tabular}

Notes: Regressions are Ordered Logits. The dependent variable is 'self-reported satisfaction'. *, ** and *** indicate significance at the $10 \%, 5 \%$ and $1 \%$ level. Clustered standard errors are reported in parenthesis. 
Model 2: Olympic Games (Excluding 1984)

\begin{tabular}{|c|c|c|c|c|c|c|c|c|c|}
\hline $\begin{array}{l}\text { Restrictions } \\
\text { Sport Variables }\end{array}$ & None & Aged $\geq 50$ & Aged $<50$ & Males & Females & Employed & $\begin{array}{l}\text { No Higher } \\
\text { Education }\end{array}$ & $\begin{array}{l}\text { In Upper } \\
\text { Income }\end{array}$ & $\begin{array}{l}\text { Not in } \\
\text { Upper Inc. }\end{array}$ \\
\hline \multirow[t]{2}{*}{ (Actual-Predicted) } & 0.013 & 0.003 & $0.02 * *$ & $0.018^{*}$ & 0.008 & 0.012 & 0.013 & $0.018^{*}$ & 0.011 \\
\hline & $(0.009)$ & $(0.01)$ & $(0.01)$ & $(0.01)$ & $(0.009)$ & $(0.009)$ & $(0.009)$ & $(0.011)$ & $(0.009)$ \\
\hline \multirow[t]{2}{*}{ Host } & -0.128 & 0.014 & -0.209 & $-0.256^{* *}$ & -0.019 & -0.121 & -0.038 & $-0.341^{* * *}$ & 0.114 \\
\hline & $(0.125)$ & $(0.109)$ & $(0.153)$ & $(0.119)$ & $(0.13)$ & $(0.125)$ & $(0.123)$ & $(0.114)$ & $(0.139)$ \\
\hline \multicolumn{10}{|l|}{ Macro Variables } \\
\hline \multirow[t]{2}{*}{ GDP p.c. } & 0.00001 & -0.00001 & 0.00001 & 0.00001 & -0.00001 & 0.00001 & 0.00001 & 0.00001 & 0.00001 \\
\hline & $(0.00002)$ & $(0.00002)$ & $(0.00002)$ & $(0.00002)$ & $(0.00001)$ & $(0.00002)$ & $(0.00001)$ & $(0.00002)$ & $(0.00002)$ \\
\hline \multirow[t]{2}{*}{ Unemployment } & $-3.661 *$ & $-4.319 * *$ & -3.459 & -2.383 & $-4.789 * *$ & $-3.418^{*}$ & $-4.654 * *$ & -2.211 & $-4.60 * *$ \\
\hline & $(2.09)$ & $(2.145)$ & $(2.326)$ & $(2.165)$ & $(2.04)$ & $(2.077)$ & $(2.094)$ & $(2.387)$ & (2.097) \\
\hline \multirow[t]{2}{*}{ Inflation } & -1.613 & -1.427 & -1.466 & -1.45 & -1.823 & -1.653 & -1.257 & -1.309 & -1.955 \\
\hline & (2.193) & $(1.909)$ & $(2.466)$ & $(2.399)$ & $(2.029)$ & (2.197) & $(2.229)$ & $(1.959)$ & $(2.736)$ \\
\hline \multicolumn{10}{|l|}{ Personal Controls } \\
\hline Unemployed & $\begin{array}{c}-0.955^{* * *} \\
(0.087)\end{array}$ & $\begin{array}{c}-0.76^{* * *} \\
(0.145)\end{array}$ & $\begin{array}{c}-1.046^{* * *} \\
(0.087)\end{array}$ & $\begin{array}{c}-1.246^{* * *} \\
(0.103)\end{array}$ & $\begin{array}{c}-0.696^{* * *} \\
(0.107)\end{array}$ & & $\begin{array}{c}-1.038^{* * *} \\
(0.083)\end{array}$ & $\begin{array}{c}-0.695^{* * *} \\
(0.138)\end{array}$ & $\begin{array}{c}-1.044^{* * *} \\
(0.082)\end{array}$ \\
\hline \multirow[t]{2}{*}{ Self employed } & $0.077^{\prime}$ & 0.075 & 0.079 & 0.064 & 0.086 & 0.076 & 0.047 & $0.105^{* *}$ & 0.024 \\
\hline & $(0.048)$ & $(0.077)$ & $(0.054)$ & $(0.055)$ & $(0.063)$ & $(0.048)$ & $(0.058)$ & $(0.05)$ & $(0.078)$ \\
\hline \multirow{2}{*}{ Male } & $-0.091 * * *$ & 0.01 & $-0.145^{* * *}$ & & & $-0.062 * *$ & $-0.076^{* *}$ & $-0.111^{* *}$ & $-0.069 *$ \\
\hline & $(0.032)$ & $(0.046)$ & $(0.034)$ & & & $(0.03)$ & $(0.032)$ & $(0.046)$ & $(0.039)$ \\
\hline \multirow[t]{2}{*}{ Married } & $0.258^{* * *}$ & $0.156^{*}$ & $0.337^{* * *}$ & $0.177^{* * *}$ & $0.32^{* * *}$ & $0.25^{\text {*** }}$ & $0.221^{* * *}$ & $0.226^{* * *}$ & $0.284 * * *$ \\
\hline & $(0.041)$ & $(0.093)$ & $(0.044)$ & $(0.052)$ & $(0.054)$ & $(0.042)$ & $(0.05)$ & $(0.046)$ & $(0.054)$ \\
\hline \multirow{2}{*}{ Defacto Married } & -0.013 & -0.184 & 0.049 & -0.086 & 0.06 & 0.003 & -0.068 & -0.047 & -0.01 \\
\hline & $(0.063)$ & $(0.134)$ & $(0.07)$ & $(0.083)$ & $(0.075)$ & $(0.063)$ & $(0.073)$ & $(0.083)$ & $(0.092)$ \\
\hline \multirow[t]{2}{*}{ Divorced } & $-0.312^{* * *}$ & $-0.336^{* *}$ & $-0.273^{* * *}$ & $-0.282^{* * *}$ & $-0.318^{* * *}$ & $-0.303^{* * *}$ & $-0.393^{* * *}$ & -0.117 & $-0.337 * * *$ \\
\hline & $(0.084)$ & $(0.132)$ & $(0.095)$ & $(0.107)$ & $(0.107)$ & $(0.088)$ & $(0.093)$ & (0.144) & $(0.083)$ \\
\hline \multirow[t]{2}{*}{ Separated } & $-0.35^{* * *}$ & $-0.424 * *$ & $-0.29 *$ & 0.022 & $-0.526 * * *$ & $-0.312^{* *}$ & $-0.473^{* * *}$ & -0.05 & $-0.429 * * *$ \\
\hline & $(0.121)$ & $(0.193)$ & $(0.151)$ & $(0.235)$ & $(0.115)$ & $(0.121)$ & $(0.147)$ & $(0.205)$ & $(0.132)$ \\
\hline \multirow[t]{2}{*}{ Widowed } & $-0.23^{* * *}$ & $-0.214 * *$ & $-0.37^{* *}$ & $-0.433^{* * *}$ & -0.075 & $-0.236^{* * *}$ & $-0.262^{* * *}$ & -0.147 & $-0.216^{* * *}$ \\
\hline & $(0.06)$ & $(0.095)$ & $(0.145)$ & $(0.10)$ & $(0.074)$ & $(0.062)$ & $(0.068)$ & $(0.127)$ & $(0.066)$ \\
\hline \multirow[t]{2}{*}{ Second Income Quar. } & $0.15^{* * *}$ & $0.128^{* *}$ & $0.144^{* * *}$ & $0.168^{* * *}$ & $0.112^{* *}$ & $0.142^{* * *}$ & $0.153^{* * *}$ & & $0.153^{* * *}$ \\
\hline & $(0.04)$ & $(0.051)$ & $(0.047)$ & $(0.048)$ & $(0.051)$ & $(0.038)$ & $(0.042)$ & & $(0.042)$ \\
\hline Third Income Quar. & $0.293^{* * *}$ & $0.229 * * *$ & $0.309 * * *$ & $0.272^{* * *}$ & $0.296^{* * *}$ & $0.273^{* * *}$ & $0.288^{* * *}$ & $-0.264^{* * *}$ & \\
\hline & $(0.048)$ & $(0.068)$ & $(0.045)$ & $(0.061)$ & $(0.052)$ & $(0.048)$ & $(0.051)$ & $(0.036)$ & \\
\hline Fourth Income Quar. & $0.529 * * *$ & $0.537^{* * *}$ & $0.531^{* * *}$ & $0.514 * * *$ & $0.535^{* * *}$ & $0.512 * * *$ & $0.513^{* * *}$ & & \\
\hline & $(0.045)$ & $(0.075)$ & $(0.045)$ & $(0.05)$ & $(0.055)$ & $(0.045)$ & $(0.054)$ & & \\
\hline Age & $-0.055^{* * *}$ & 0.051 & $-0.09 * * *$ & $-0.06^{* * *}$ & $-0.049 * * *$ & $-0.052^{* * *}$ & $-0.053^{* * *}$ & $-0.06^{* * *}$ & $-0.05^{* * *}$ \\
\hline & $(0.005)$ & $(0.032)$ & $(0.013)$ & $(0.008)$ & $(0.006)$ & $(0.005)$ & $(0.006)$ & $(0.01)$ & $(0.006)$ \\
\hline $\mathrm{Age}^{2}$ & $0.001^{* * *}$ & -0.0002 & $0.001^{* * *}$ & $0.001 * * *$ & $0.001 * * *$ & $0.001^{* * *}$ & $0.001^{* * *}$ & $0.001 * * *$ & $0.001^{* * *}$ \\
\hline & $(0.0001)$ & $(0.0002)$ & $(0.0002)$ & $(0.0001)$ & $(0.0001)$ & $(0.0001)$ & $(0.0001)$ & $(0.0001)$ & $(0.0001)$ \\
\hline Lower Education & -0.002 & 0.056 & 0.014 & 0.008 & -0.008 & -0.001 & 0.006 & 0.044 & -0.02 \\
\hline & $(0.057)$ & $(0.077)$ & $(0.065)$ & $(0.059)$ & $(0.069)$ & $(0.058)$ & $(0.053)$ & $(0.07)$ & $(0.064)$ \\
\hline Secondary Education & 0.014 & $0.16^{*}$ & -0.015 & 0.043 & -0.015 & 0.025 & 0.022 & 0.054 & 0.028 \\
\hline & $(0.057)$ & $(0.095)$ & $(0.062)$ & $(0.069)$ & $(0.069)$ & $(0.057)$ & $(0.054)$ & $(0.066)$ & $(0.071)$ \\
\hline Higher Education & $0.205^{* * *}$ & $0.276^{* * *}$ & $0.202^{* * *}$ & $0.232^{* * *}$ & $0.188^{* * *}$ & $0.198^{* * *}$ & & $0.235^{* * *}$ & $0.223^{* * *}$ \\
\hline & $(0.056)$ & $(0.101)$ & (0.059) & $(0.06)$ & $(0.068)$ & $(0.057)$ & & $(0.056)$ & $(0.08)$ \\
\hline Retired & 0.062 & 0.081 & $-0.399 *$ & 0.031 & 0.028 & 0.069 & 0.058 & $0.157^{*}$ & -0.011 \\
\hline & $(0.055)$ & $(0.073)$ & $(0.225)$ & $(0.085)$ & $(0.062)$ & $(0.056)$ & $(0.057)$ & $(0.085)$ & $(0.066)$ \\
\hline Home & 0.044 & 0.057 & 0.045 & 0.091 & 0.032 & 0.06 & 0.04 & $0.166^{* * *}$ & -0.048 \\
\hline & $(0.043)$ & $(0.062)$ & $(0.048)$ & $(0.187)$ & $(0.043)$ & $(0.043)$ & $(0.045)$ & $(0.054)$ & $(0.06)$ \\
\hline School & $0.148^{* * *}$ & -0.386 & $0.098^{*}$ & 0.123 & $0.181^{* *}$ & $0.16^{* * *}$ & 0.103 & 0.003 & $0.24^{* * *}$ \\
\hline & $(0.054)$ & $(0.235)$ & $(0.053)$ & $(0.082)$ & $(0.072)$ & $(0.059)$ & $(0.062)$ & $(0.079)$ & $(0.079)$ \\
\hline Number of Obs. & 35,766 & 13,601 & 22,165 & 17,653 & 18,113 & 34,121 & 27,226 & 15,995 & 19,771 \\
\hline Pseudo-R2 & 0.0812 & 0.0804 & 0.0861 & 0.080 & 0.0853 & 0.077 & 0.0715 & 0.0872 & 0.0733 \\
\hline Year Effects & Yes & Yes & Yes & Yes & Yes & Yes & Yes & Yes & Yes \\
\hline Country Effects & Yes & Yes & Yes & Yes & Yes & Yes & Yes & Yes & Yes \\
\hline
\end{tabular}

Notes: Regressions are Ordered Logits. The dependent variable is ‘self-reported satisfaction' . *, ** and *** indicate significance at the $10 \%, 5 \%$ and $1 \%$ level. Clustered standard errors are reported in parenthesis. 
Models 3 and 4 report results using actual medals won in the previous Games as predictions.

Model 3: Olympic Games

\begin{tabular}{|c|c|c|c|c|c|c|c|c|c|}
\hline Restrictions & None & Aged $\geq 50$ & Aged $<50$ & Males & Females & Employed & $\begin{array}{l}\text { No Higher } \\
\text { Education }\end{array}$ & $\begin{array}{l}\text { In Upper } \\
\text { Income }\end{array}$ & $\begin{array}{l}\text { Not in } \\
\text { Upper Inc. }\end{array}$ \\
\hline \multicolumn{10}{|l|}{ Sport Variables } \\
\hline (Actual-Actual Lagged) & $\begin{array}{c}0.001 \\
(0.005)\end{array}$ & $\begin{array}{c}0.005 \\
(0.005)\end{array}$ & $\begin{array}{l}-0.001 \\
(0.005)\end{array}$ & $\begin{array}{l}0.0002 \\
(0.005)\end{array}$ & $\begin{array}{c}0.003 \\
(0.005)\end{array}$ & $\begin{array}{c}0.001 \\
(0.005)\end{array}$ & $\begin{array}{c}0.002 \\
(0.005)\end{array}$ & $\begin{array}{c}0.001 \\
(0.004)\end{array}$ & $\begin{array}{c}0.002 \\
(0.005)\end{array}$ \\
\hline Host & $\begin{array}{l}-0.156 \\
(0.123)\end{array}$ & $\begin{array}{l}-0.087 \\
(0.129)\end{array}$ & $\begin{array}{l}-0.187 \\
(0.129)\end{array}$ & $\begin{array}{l}-0.22^{*} \\
(0.114)\end{array}$ & $\begin{array}{l}-0.101 \\
(0.144)\end{array}$ & $\begin{array}{l}-0.147 \\
(0.123)\end{array}$ & $\begin{array}{l}-0.085 \\
(0.131)\end{array}$ & $\begin{array}{c}-0.359 * * * \\
(0.112)\end{array}$ & $\begin{array}{c}0.065 \\
(0.148)\end{array}$ \\
\hline \multicolumn{10}{|l|}{ Macro Variables } \\
\hline GDP p.c. & $\begin{array}{c}0.00001 \\
(0.00001)\end{array}$ & $\begin{array}{c}0.00001 \\
(0.00001)\end{array}$ & $\begin{array}{c}0.00002 \\
(0.00002)\end{array}$ & $\begin{array}{c}0.00002 \\
(0.00002)\end{array}$ & $\begin{array}{c}0.00001 \\
(0.00001)\end{array}$ & $\begin{array}{c}0.00001 \\
(0.00001)\end{array}$ & $\begin{array}{l}0.00001 \\
(0.00001)\end{array}$ & $\begin{array}{c}0.00001 \\
(0.00002)\end{array}$ & $\begin{array}{c}0.00001 \\
(0.00001)\end{array}$ \\
\hline Unemployment & $\begin{array}{l}-3.763 * \\
(2.017)\end{array}$ & $\begin{array}{c}-4.376 * * \\
(2.091)\end{array}$ & $\begin{array}{l}-3.502 \\
(2.194)\end{array}$ & $\begin{array}{l}-3.308 \\
(2.20)\end{array}$ & $\begin{array}{l}-4.117 * * \\
(1.95)\end{array}$ & $\begin{array}{l}-3.508^{*} \\
(2.025)\end{array}$ & $\begin{array}{c}-4.534 * * \\
(2.099)\end{array}$ & $\begin{array}{l}-3.073 \\
(2.489)\end{array}$ & $\begin{array}{l}-4.14 * * \\
(1.881)\end{array}$ \\
\hline $\begin{array}{l}\text { Inflation } \\
\text { Personal Controls }\end{array}$ & $\begin{array}{l}-2.801 \\
(1.909)\end{array}$ & $\begin{array}{l}-1.46 \\
(1.747)\end{array}$ & $\begin{array}{l}-3.791 * \\
(2.129)\end{array}$ & $\begin{array}{l}-3.166 \\
(2.174)\end{array}$ & $\begin{array}{l}-2.456 \\
(1.726)\end{array}$ & $\begin{array}{l}-2.711 \\
(1.897)\end{array}$ & $\begin{array}{l}-2.364 \\
(1.899)\end{array}$ & $\begin{array}{l}-2.949 \\
(1.887)\end{array}$ & $\begin{array}{l}-2.892 \\
(2.18)\end{array}$ \\
\hline Unemployed & $\begin{array}{c}-0.925^{* * *} \\
(0.083)\end{array}$ & $\begin{array}{c}-0.757^{* * *} \\
(0.118)\end{array}$ & $\begin{array}{c}-1.014 * * * \\
(0.087)\end{array}$ & $\begin{array}{c}-1.167 * * * \\
(0.10)\end{array}$ & $\begin{array}{l}-0.708^{* * *} \\
(0.094)\end{array}$ & & $\begin{array}{l}-0.975^{* * *} \\
(0.085)\end{array}$ & $\begin{array}{c}-0.698^{* * *} \\
(0.117)\end{array}$ & $\begin{array}{c}-1.015^{* * *} \\
(0.08)\end{array}$ \\
\hline Self employed & $\begin{array}{l}0.081^{* *} \\
(0.041)\end{array}$ & $\begin{array}{l}0.063 \\
(0.067)\end{array}$ & $\begin{array}{l}0.088^{*} \\
(0.048)\end{array}$ & $\begin{array}{c}0.062 \\
(0.046)\end{array}$ & $\begin{array}{l}0.098^{*} \\
(0.06)\end{array}$ & $\begin{array}{l}0.081^{* *} \\
(0.041)\end{array}$ & $\begin{array}{c}0.055 \\
(0.049)\end{array}$ & $\begin{array}{l}0.105^{* *} \\
(0.041)\end{array}$ & $\begin{array}{c}0.033 \\
(0.069)\end{array}$ \\
\hline Male & $\begin{array}{c}-0.09 * * * \\
(0.031)\end{array}$ & $\begin{array}{c}0.003 \\
(0.043)\end{array}$ & $\begin{array}{c}-0.139 * * * \\
(0.035)\end{array}$ & & & $\begin{array}{c}-0.064 * * \\
(0.029)\end{array}$ & $\begin{array}{c}-0.078^{* *} \\
(0.031)\end{array}$ & $\begin{array}{c}-0.098 * * \\
(0.046)\end{array}$ & $\begin{array}{c}-0.075^{* *} \\
(0.037)\end{array}$ \\
\hline Married & $\begin{array}{c}0.235^{* * *} \\
(\mathbf{0 . 0 3 8 )}\end{array}$ & $\begin{array}{c}0.106 \\
(0.086)\end{array}$ & $\begin{array}{c}0.317^{* * *} \\
(0.041)\end{array}$ & $\begin{array}{c}0.171^{* * *} \\
(0.05)\end{array}$ & $\begin{array}{c}0.278^{* * *} \\
(0.049)\end{array}$ & $\begin{array}{c}0.225^{* * *} \\
(0.039)\end{array}$ & $\begin{array}{c}\mathbf{0 . 2 0 6}{ }^{* * *} \\
(\mathbf{0 . 0 4 6 )}\end{array}$ & $\begin{array}{c}0.243 * * * \\
(0.044)\end{array}$ & $\begin{array}{c}0.233^{* * *} \\
(0.052)\end{array}$ \\
\hline Defacto Married & $\begin{array}{c}0.012 \\
(0.057)\end{array}$ & $\begin{array}{c}-0.258^{* *} \\
(0.122)\end{array}$ & $\begin{array}{c}0.083 \\
(0.061)\end{array}$ & $\begin{array}{l}-0.049 \\
(0.076)\end{array}$ & $\begin{array}{c}0.064 \\
(0.068)\end{array}$ & $\begin{array}{c}0.02 \\
(0.058)\end{array}$ & $\begin{array}{l}-0.021 \\
(0.071)\end{array}$ & $\begin{array}{c}0.015 \\
(0.078)\end{array}$ & $\begin{array}{l}-0.001 \\
(0.082)\end{array}$ \\
\hline Divorced & $\begin{array}{c}-0.305^{* * *} \\
(0.075)\end{array}$ & $\begin{array}{c}-0.363^{* * *} \\
(0.117)\end{array}$ & $\begin{array}{c}-0.259 * * * \\
(0.085)\end{array}$ & $\begin{array}{c}-0.217 * * \\
(0.097)\end{array}$ & $\begin{array}{c}-0.359 * * * \\
(0.098)\end{array}$ & $\begin{array}{c}-0.295^{* * *} \\
(0.08)\end{array}$ & $\begin{array}{c}-0.38 * * * \\
(0.085)\end{array}$ & $\begin{array}{l}-0.118 \\
(0.117)\end{array}$ & $\begin{array}{c}-0.343^{* * *} \\
(0.076)\end{array}$ \\
\hline Separated & $\begin{array}{c}-0.421 * * * \\
(0.108)\end{array}$ & $\begin{array}{c}-0.648^{* * *} \\
(0.209)\end{array}$ & $\begin{array}{c}-0.303^{* *} \\
(0.134)\end{array}$ & $\begin{array}{l}-0.099 \\
(0.204)\end{array}$ & $\begin{array}{c}-0.581^{* * *} \\
(0.11)\end{array}$ & $\begin{array}{c}-0.406^{* * *} \\
(0.113)\end{array}$ & $\begin{array}{c}-0.541^{* * *} \\
(0.13)\end{array}$ & $\begin{array}{l}-0.171 \\
(0.203)\end{array}$ & $\begin{array}{c}-0.492 * * * \\
(0.124)\end{array}$ \\
\hline Widowed & $\begin{array}{c}-0.25^{* * *} \\
(0.055)\end{array}$ & $\begin{array}{c}-0.29 * * * \\
(0.086)\end{array}$ & $\begin{array}{l}-0.27^{*} \\
(0.142)\end{array}$ & $\begin{array}{c}-0.404 * * * \\
(0.096)\end{array}$ & $\begin{array}{l}-0.126^{*} \\
(0.065)\end{array}$ & $\begin{array}{c}-0.257^{* * *} \\
(0.056)\end{array}$ & $\begin{array}{c}-0.282^{* * *} \\
(0.061)\end{array}$ & $\begin{array}{c}-0.204^{*} \\
(0.112)\end{array}$ & $\begin{array}{c}-0.247^{* * *} \\
(0.059)\end{array}$ \\
\hline Second Income Quar. & $\begin{array}{c}0.166^{* * *} \\
(0.038)\end{array}$ & $\begin{array}{l}0.122^{* *} \\
(0.048)\end{array}$ & $\begin{array}{l}0.19 * * * \\
(0.047)\end{array}$ & $\begin{array}{c}0.171^{* * *} \\
(0.043)\end{array}$ & $\begin{array}{c}0.142^{* * *} \\
(0.049)\end{array}$ & $\begin{array}{c}0.156^{* * *} \\
(0.038)\end{array}$ & $\begin{array}{l}0.17 * * * \\
(0.039)\end{array}$ & & $\begin{array}{c}0.173 * * * \\
(0.039)\end{array}$ \\
\hline Third Income Quar. & $\begin{array}{c}0.324 * * * \\
(0.045)\end{array}$ & $\begin{array}{c}0.257^{* * *} \\
(0.063)\end{array}$ & $\begin{array}{c}0.356^{* * *} \\
(0.046)\end{array}$ & $\begin{array}{c}0.306^{* * *} \\
(0.054)\end{array}$ & $\begin{array}{c}0.322 * * * \\
(0.051)\end{array}$ & $\begin{array}{c}0.307^{* * *} \\
(0.045)\end{array}$ & $\begin{array}{l}0.32^{* * *} \\
(0.048)\end{array}$ & & \\
\hline Fourth Income Quar. & $\begin{array}{l}0.58 * * * \\
(0.045)\end{array}$ & $\begin{array}{c}0.579 * * * \\
(0.067)\end{array}$ & $\begin{array}{c}0.597^{* * *} \\
(0.047)\end{array}$ & $\begin{array}{c}0.562^{* * *} \\
(0.05)\end{array}$ & $\begin{array}{c}0.587 * * * \\
(0.054)\end{array}$ & $\begin{array}{c}0.563 * * * \\
(0.045)\end{array}$ & $\begin{array}{c}0.575^{* * *} \\
(0.052)\end{array}$ & $\begin{array}{c}0.282 * * * \\
(0.033)\end{array}$ & \\
\hline Age & $\begin{array}{c}-0.051^{* * *} \\
(0.005)\end{array}$ & $\begin{array}{l}0.049^{*} \\
(0.029)\end{array}$ & $\begin{array}{c}-0.088^{* * *} \\
(0.011)\end{array}$ & $\begin{array}{c}-0.053^{* * *} \\
(0.007)\end{array}$ & $\begin{array}{c}-0.046^{* * *} \\
(0.006)\end{array}$ & $\begin{array}{c}-0.048^{* * * *} \\
(0.005)\end{array}$ & $\begin{array}{c}-0.049 * * * \\
(0.005)\end{array}$ & $\begin{array}{c}-0.053^{* * *} \\
(0.009)\end{array}$ & $\begin{array}{c}-0.048^{* * *} \\
(0.006)\end{array}$ \\
\hline Age $^{2}$ & $\begin{array}{l}0.001 * * * \\
(0.0001)\end{array}$ & $\begin{array}{l}-0.0002 \\
(0.0002)\end{array}$ & $\begin{array}{l}0.001 * * * \\
(0.0002)\end{array}$ & $\begin{array}{l}0.001^{* * *} \\
(0.0001)\end{array}$ & $\begin{array}{l}0.001 * * * \\
(0.0001)\end{array}$ & $\begin{array}{l}0.001 * * * \\
(0.0001)\end{array}$ & $\begin{array}{l}0.001 * * * \\
(0.0001)\end{array}$ & $\begin{array}{l}0.001 * * * \\
(0.0001)\end{array}$ & $\begin{array}{l}0.001^{* * *} \\
(0.0001)\end{array}$ \\
\hline Lower Education & $\begin{array}{c}0.011 \\
(0.048)\end{array}$ & $\begin{array}{c}0.064 \\
(0.067)\end{array}$ & $\begin{array}{c}0.03 \\
(0.056)\end{array}$ & $\begin{array}{c}0.003 \\
(0.051)\end{array}$ & $\begin{array}{c}0.02 \\
(0.057)\end{array}$ & $\begin{array}{c}0.013 \\
(0.049)\end{array}$ & $\begin{array}{c}0.019 \\
(0.045)\end{array}$ & $\begin{array}{c}0.035 \\
(0.055)\end{array}$ & $\begin{array}{l}-0.002 \\
(0.057)\end{array}$ \\
\hline Secondary Education & $\begin{array}{c}0.032 \\
(0.051)\end{array}$ & $\begin{array}{l}0.166^{* *} \\
(0.084)\end{array}$ & $\begin{array}{c}0.013 \\
(0.056)\end{array}$ & $\begin{array}{c}0.052 \\
(0.064)\end{array}$ & $\begin{array}{c}0.004 \\
(0.061)\end{array}$ & $\begin{array}{c}0.045 \\
(0.051)\end{array}$ & $\begin{array}{c}0.038 \\
(0.048)\end{array}$ & $\begin{array}{c}0.063 \\
(0.062)\end{array}$ & $\begin{array}{c}0.05 \\
(0.063)\end{array}$ \\
\hline Higher Education & $\begin{array}{c}0.206 * * * \\
(0.051)\end{array}$ & $\begin{array}{c}0.282 * * * \\
(0.087)\end{array}$ & $\begin{array}{c}0.208 * * * \\
(0.058)\end{array}$ & $\begin{array}{c}0.224 * * * \\
(0.057)\end{array}$ & $\begin{array}{c}0.195 * * * \\
(0.059)\end{array}$ & $\begin{array}{c}0.205^{* * *} \\
(0.052)\end{array}$ & & $\begin{array}{c}0.219 * * * \\
(0.053)\end{array}$ & $\begin{array}{c}0.223 * * * \\
(0.072)\end{array}$ \\
\hline Retired & $\begin{array}{l}0.071 \\
(0.05)\end{array}$ & $\begin{array}{l}0.076 \\
(0.063)\end{array}$ & $\begin{array}{l}-0.361 * \\
(0.216)\end{array}$ & $\begin{array}{c}0.052 \\
(0.075)\end{array}$ & $\begin{array}{c}0.032 \\
(0.055)\end{array}$ & $\begin{array}{l}0.081 \\
(0.05)\end{array}$ & $\begin{array}{c}0.071 \\
(0.051)\end{array}$ & $\begin{array}{l}0.147^{*} \\
(0.077)\end{array}$ & $\begin{array}{l}0.004 \\
(0.059)\end{array}$ \\
\hline Home & $\begin{array}{c}0.063 \\
(0.042)\end{array}$ & $\begin{array}{c}0.06 \\
(0.057)\end{array}$ & $\begin{array}{l}0.069 \\
(0.046)\end{array}$ & $\begin{array}{c}0.089 \\
(0.188)\end{array}$ & $\begin{array}{c}0.05 \\
(0.041)\end{array}$ & $\begin{array}{l}0.079^{*} \\
(0.041)\end{array}$ & $\begin{array}{c}0.063 \\
(0.046)\end{array}$ & $\begin{array}{l}0.18^{* * *} \\
(0.051)\end{array}$ & $\begin{array}{l}-0.029 \\
(0.054)\end{array}$ \\
\hline School & $\begin{array}{c}0.197 * * * \\
(0.061) \\
\end{array}$ & $\begin{array}{l}-0.324 \\
(0.198) \\
\end{array}$ & $\begin{array}{l}0.148^{* *} \\
(0.062)\end{array}$ & $\begin{array}{l}0.195^{* *} \\
(0.084)\end{array}$ & $\begin{array}{c}0.203 * * * \\
(0.072) \\
\end{array}$ & $\begin{array}{c}0.203 * * * \\
(0.064) \\
\end{array}$ & $\begin{array}{l}0.159 * * \\
(0.066)\end{array}$ & $\begin{array}{l}0.097 \\
0.082 \\
\end{array}$ & $\begin{array}{r}0.263^{* * *} \\
(0.078) \\
\end{array}$ \\
\hline $\begin{array}{l}\text { Number of Obs. } \\
\text { Pseudo-R2 }\end{array}$ & $\begin{array}{l}44,440 \\
0.0825 \\
\end{array}$ & $\begin{array}{l}16,806 \\
0.0812 \\
\end{array}$ & $\begin{array}{l}27,634 \\
0.0872 \\
\end{array}$ & $\begin{array}{c}21,893 \\
0.080 \\
\end{array}$ & $\begin{array}{l}22,547 \\
0.0873 \\
\end{array}$ & $\begin{array}{l}42,286 \\
0.0791\end{array}$ & $\begin{array}{l}34,251 \\
0.0744\end{array}$ & $\begin{array}{l}20,472 \\
0.0864\end{array}$ & $\begin{array}{c}23,968 \\
0.075 \\
\end{array}$ \\
\hline Year Effects & Yes & Yes & Yes & Yes & Yes & Yes & Yes & Yes & Yes \\
\hline Country Effects & Yes & Yes & Yes & Yes & Yes & Yes & Yes & Yes & Yes \\
\hline
\end{tabular}

Notes: Regressions are Ordered Logits. The dependent variable is ‘self-reported satisfaction’ * , ** and *** indicate significance at the $10 \%, 5 \%$ and $1 \%$ level. Clustered standard errors are reported in parenthesis. 
Model 4: Olympic Games (Excluding 1984)

\begin{tabular}{|c|c|c|c|c|c|c|c|c|c|}
\hline Restrictions & None & Aged $\geq 50$ & Aged $<50$ & Males & Females & Employed & $\begin{array}{l}\text { No Higher } \\
\text { Education }\end{array}$ & $\begin{array}{l}\text { In Upper } \\
\text { Income }\end{array}$ & $\begin{array}{c}\text { Not in } \\
\text { Upper Inc. }\end{array}$ \\
\hline \multicolumn{10}{|l|}{ Sport Variables } \\
\hline (Actual-Actual Lagged) & $\begin{array}{l}0.009 * * \\
(0.004)\end{array}$ & $\begin{array}{l}0.008^{* *} \\
(0.004)\end{array}$ & $\begin{array}{l}0.009^{*} \\
(0.005)\end{array}$ & $\begin{array}{c}0.008 \\
(0.005)\end{array}$ & $\begin{array}{c}0.009 * * * \\
(0.004)\end{array}$ & $\begin{array}{l}0.008^{* *} \\
(0.004)\end{array}$ & $\begin{array}{l}0.009 \text { ** } \\
(0.004)\end{array}$ & $\begin{array}{l}0.008^{*} \\
(0.004)\end{array}$ & $\begin{array}{c}0.01 * * \\
(0.004)\end{array}$ \\
\hline Host & $\begin{array}{l}-0.264 * \\
(0.137)\end{array}$ & $\begin{array}{l}-0.135 \\
(0.124)\end{array}$ & $\begin{array}{c}-0.336^{* *} \\
(0.159)\end{array}$ & $\begin{array}{c}-0.351^{* *} \\
(0.141)\end{array}$ & $\begin{array}{c}-0.188 \\
(0.14)\end{array}$ & $\begin{array}{c}-0.25^{*} \\
(0.135)\end{array}$ & $\begin{array}{l}-0.181 \\
(0.136)\end{array}$ & $\begin{array}{c}-0.461 \text { *** } \\
(0.13)\end{array}$ & $\begin{array}{c}-0.05 \\
(0.152)\end{array}$ \\
\hline \multicolumn{10}{|l|}{ Macro Variables } \\
\hline GDP p.c. & $\begin{array}{c}0.00001 \\
(0.00002)\end{array}$ & $\begin{array}{l}-0.00001 \\
(0.00002)\end{array}$ & $\begin{array}{c}0.00001 \\
(0.00002)\end{array}$ & $\begin{array}{c}0.00002 \\
(0.00002)\end{array}$ & $\begin{array}{c}0.00001 \\
(0.00001)\end{array}$ & $\begin{array}{c}0.00001 \\
(0.00002)\end{array}$ & $\begin{array}{c}0.00001 \\
(0.00001)\end{array}$ & $\begin{array}{c}0.00001 \\
(0.00002)\end{array}$ & $\begin{array}{c}0.00001 \\
(0.00002)\end{array}$ \\
\hline Unemployment & $\begin{array}{l}-3.80 * \\
(2.06)\end{array}$ & $\begin{array}{l}-4.27 * * \\
(2.111)\end{array}$ & $\begin{array}{l}-3.726 \\
(2.317)\end{array}$ & $\begin{array}{l}-2.621 \\
(2.19)\end{array}$ & $\begin{array}{c}-4.827^{* *} \\
(2.00)\end{array}$ & $\begin{array}{l}-3.555^{*} \\
(2.049)\end{array}$ & $\begin{array}{c}-4.791^{* *} \\
\mathbf{( 2 . 0 4 8 )}\end{array}$ & $\begin{array}{l}-2.492 \\
(2.429)\end{array}$ & $\begin{array}{c}-5.657^{* *} \\
(2.041)\end{array}$ \\
\hline $\begin{array}{l}\text { Inflation } \\
\text { Personal Controls }\end{array}$ & $\begin{array}{l}-2.377 \\
(2.009)\end{array}$ & $\begin{array}{l}-1.286 \\
(1.785)\end{array}$ & $\begin{array}{l}-3.27 \\
(2.259)\end{array}$ & $\begin{array}{l}-2.746 \\
(2.275)\end{array}$ & $\begin{array}{c}-2.05 \\
(1.822)\end{array}$ & $\begin{array}{l}-2.346 \\
(1.982)\end{array}$ & $\begin{array}{l}-1.948 \\
(1.998)\end{array}$ & $\begin{array}{l}-2.597 \\
(1.837)\end{array}$ & $\begin{array}{l}-2.401 \\
(2.464)\end{array}$ \\
\hline Unemployed & $\begin{array}{c}-0.959 * * * \\
(0.086)\end{array}$ & $\begin{array}{c}-0.771^{* * *} \\
(0.145)\end{array}$ & $\begin{array}{c}-1.05^{* * *} \\
(0.086)\end{array}$ & $\begin{array}{c}-1.255^{* * *} \\
(0.103)\end{array}$ & $\begin{array}{c}-0.701^{* * *} \\
(0.106)\end{array}$ & & $\begin{array}{c}-1.042^{* * *} \\
(0.083)\end{array}$ & $\begin{array}{c}-0.703 * * * \\
(0.137)\end{array}$ & $\begin{array}{c}-1.044 * * * \\
(0.081)\end{array}$ \\
\hline Self employed & $\begin{array}{c}0.076 \\
(0.047)\end{array}$ & $\begin{array}{c}0.063 \\
(0.076)\end{array}$ & $\begin{array}{c}0.081 \\
(0.052)\end{array}$ & $\begin{array}{l}0.067 \\
(0.054)\end{array}$ & $\begin{array}{c}0.075 \\
(0.063)\end{array}$ & $\begin{array}{c}0.075 \\
(0.047)\end{array}$ & $\begin{array}{c}0.044 \\
(0.057)\end{array}$ & $\begin{array}{l}0.101^{* *} \\
(0.049)\end{array}$ & $\begin{array}{c}0.024 \\
(0.077)\end{array}$ \\
\hline Male & $\begin{array}{c}-0.097 * * * \\
(0.032)\end{array}$ & $\begin{array}{l}-0.001 \\
(0.046)\end{array}$ & $\begin{array}{c}-0.149 * * * \\
(0.033)\end{array}$ & & & $\begin{array}{c}-0.069 * * \\
(0.03)\end{array}$ & $\begin{array}{c}-0.081 * * \\
(0.032)\end{array}$ & $\begin{array}{c}-0.116^{* *} \\
(0.045)\end{array}$ & $\begin{array}{c}-0.076^{*} \\
(0.039)\end{array}$ \\
\hline Married & $\begin{array}{c}0.247^{* * *} \\
(0.042)\end{array}$ & $\begin{array}{c}0.152 \\
(0.093)\end{array}$ & $\begin{array}{c}0.324 * * * \\
(0.044)\end{array}$ & $\begin{array}{c}0.163^{* * *} \\
(0.052)\end{array}$ & $\begin{array}{l}0.31^{\text {**** }} \\
(0.054)\end{array}$ & $\begin{array}{c}0.239 * * * \\
(0.043)\end{array}$ & $\begin{array}{c}0.208^{* * *} \\
(0.051)\end{array}$ & $\begin{array}{c}0.213^{* * *} \\
(0.045)\end{array}$ & $\begin{array}{c}0.273^{* * *} \\
(0.055)\end{array}$ \\
\hline Defacto Married & $\begin{array}{l}-0.015 \\
(0.062)\end{array}$ & $\begin{array}{l}-0.218 \\
(0.135)\end{array}$ & $\begin{array}{c}0.053 \\
(0.069)\end{array}$ & $\begin{array}{l}-0.089 \\
(0.082)\end{array}$ & $\begin{array}{c}0.057 \\
(0.074)\end{array}$ & $\begin{array}{r}-0.0002 \\
(0.063)\end{array}$ & $\begin{array}{l}-0.073 \\
(0.072)\end{array}$ & $\begin{array}{l}-0.044 \\
(0.082)\end{array}$ & $\begin{array}{l}-0.014 \\
(0.091)\end{array}$ \\
\hline Divorced & $\begin{array}{c}-0.318^{* * *} \\
(0.082)\end{array}$ & $\begin{array}{c}-0.332 * * \\
(0.129)\end{array}$ & $\begin{array}{c}-0.285^{* * *} \\
(0.093)\end{array}$ & $\begin{array}{c}-0.272^{* *} \\
(0.106)\end{array}$ & $\begin{array}{c}-0.333 * * * \\
(0.103)\end{array}$ & $\begin{array}{c}-0.311^{* * *} \\
(0.086)\end{array}$ & $\begin{array}{c}-0.399 * * * \\
(0.09)\end{array}$ & $\begin{array}{l}-0.117 \\
(0.136)\end{array}$ & $\begin{array}{c}-0.346 * * * \\
(0.081)\end{array}$ \\
\hline Separated & $\begin{array}{c}-0.36^{* * *} \\
(0.119)\end{array}$ & $\begin{array}{c}-0.413^{* *} \\
(0.191)\end{array}$ & $\begin{array}{c}-0.313^{* *} \\
(0.149)\end{array}$ & $\begin{array}{l}-0.015 \\
(0.231)\end{array}$ & $\begin{array}{c}-0.523^{* * *} \\
(0.115)\end{array}$ & $\begin{array}{c}-0.321^{* * *} \\
(0.119)\end{array}$ & $\begin{array}{c}-0.479 * * * \\
(0.144)\end{array}$ & $\begin{array}{l}-0.103 \\
(0.206)\end{array}$ & $\begin{array}{c}-0.423 * * * \\
(0.13)\end{array}$ \\
\hline Widowed & $\begin{array}{c}-0.249 * * * \\
(0.062)\end{array}$ & $\begin{array}{c}-0.231^{* *} \\
(0.096)\end{array}$ & $\begin{array}{c}-0.379 * * * \\
(0.141)\end{array}$ & $\begin{array}{c}-0.468^{* * *} \\
(0.104)\end{array}$ & $\begin{array}{c}-0.09 \\
(0.074)\end{array}$ & $\begin{array}{c}-0.256^{* * *} \\
(0.064)\end{array}$ & $\begin{array}{c}-0.283^{* * *} \\
(0.07)\end{array}$ & $\begin{array}{l}-0.204 \\
(0.132)\end{array}$ & $\begin{array}{c}-0.228 * * * \\
(0.066)\end{array}$ \\
\hline Second Income Quar. & $\begin{array}{c}0.153^{* * *} \\
(0.039)\end{array}$ & $\begin{array}{c}0.136^{* * *} \\
(0.051)\end{array}$ & $\begin{array}{c}0.145^{* * *} \\
(0.047)\end{array}$ & $\begin{array}{c}0.169 * * * \\
(0.047)\end{array}$ & $\begin{array}{c}0.118^{* *} \\
(0.05)\end{array}$ & $\begin{array}{c}0.146^{* * *} \\
(0.038)\end{array}$ & $\begin{array}{c}0.156^{* * *} \\
(0.041)\end{array}$ & & $\begin{array}{c}0.156^{* * *} \\
(0.041)\end{array}$ \\
\hline Third Income Quar. & $\begin{array}{c}0.296^{* * *} \\
(0.047)\end{array}$ & $\begin{array}{l}0.24 * * * \\
(0.068)\end{array}$ & $\begin{array}{c}0.308^{* * *} \\
(0.044)\end{array}$ & $\begin{array}{c}0.272^{* * *} \\
(0.061)\end{array}$ & $\begin{array}{c}0.303 * * * \\
(0.052)\end{array}$ & $\begin{array}{c}0.278 * * * \\
(0.047)\end{array}$ & $\begin{array}{c}0.293^{* * *} \\
(0.051)\end{array}$ & $\begin{array}{c}-0.27^{* * *} \\
(0.036)\end{array}$ & \\
\hline Fourth Income Quar. & $\begin{array}{c}0.538 * * * \\
(0.046)\end{array}$ & $\begin{array}{c}0.547 * * * \\
(0.074)\end{array}$ & $\begin{array}{c}0.537^{* * *} \\
(0.045)\end{array}$ & $\begin{array}{c}0.528^{* * *} \\
(0.052)\end{array}$ & $\begin{array}{c}0.537 * * * \\
(0.055)\end{array}$ & $\begin{array}{c}0.523 * * * \\
(0.046)\end{array}$ & $\begin{array}{c}0.526^{* * *} \\
(0.055)\end{array}$ & & \\
\hline Age & $\begin{array}{c}-0.053^{* * *} \\
(0.005)\end{array}$ & $\begin{array}{l}0.056^{*} \\
(0.032)\end{array}$ & $\begin{array}{c}-0.09 * * * \\
(0.013)\end{array}$ & $\begin{array}{c}-0.058^{* * *} \\
(0.008)\end{array}$ & $\begin{array}{c}-0.047^{* * *} \\
(0.006)\end{array}$ & $\begin{array}{c}-0.05^{* * *} \\
(0.005)\end{array}$ & $\begin{array}{c}-0.051^{* * *} \\
(0.006)\end{array}$ & $\begin{array}{c}-0.057^{* * *} \\
(0.01)\end{array}$ & $\begin{array}{c}-0.049 * * * \\
(0.006)\end{array}$ \\
\hline Age $^{2}$ & $\begin{array}{l}0.001^{* * *} \\
(0.0001)\end{array}$ & $\begin{array}{l}-0.0003 \\
(0.0002)\end{array}$ & $\begin{array}{l}0.001^{* * *} \\
(0.0002)\end{array}$ & $\begin{array}{l}0.001^{* * *} \\
(0.0001)\end{array}$ & $\begin{array}{l}0.001^{* * *} \\
(0.0001)\end{array}$ & $\begin{array}{l}0.001^{* * *} \\
(0.0001)\end{array}$ & $\begin{array}{l}0.001^{* * *} \\
(0.0001)\end{array}$ & $\begin{array}{c}0.001^{* * *} \\
(0.0001)\end{array}$ & $\begin{array}{l}0.001 * * * \\
(0.0001)\end{array}$ \\
\hline Lower Education & $\begin{array}{l}-0.011 \\
(0.055)\end{array}$ & $\begin{array}{c}0.045 \\
(0.075)\end{array}$ & $\begin{array}{l}-0.002 \\
(0.063)\end{array}$ & $\begin{array}{l}-0.005 \\
(0.058)\end{array}$ & $\begin{array}{l}-0.011 \\
(0.066)\end{array}$ & $\begin{array}{l}-0.008 \\
(0.057)\end{array}$ & $\begin{array}{l}-0.004 \\
(0.052)\end{array}$ & $\begin{array}{c}0.026 \\
(0.068)\end{array}$ & $\begin{array}{l}-0.024 \\
(0.063)\end{array}$ \\
\hline Secondary Education & $\begin{array}{c}0.014 \\
(0.056)\end{array}$ & $\begin{array}{c}0.154^{*} \\
(0.093)\end{array}$ & $\begin{array}{l}-0.017 \\
(0.061)\end{array}$ & $\begin{array}{c}0.038 \\
(0.069)\end{array}$ & $\begin{array}{l}-0.012 \\
(0.068)\end{array}$ & $\begin{array}{c}0.025 \\
(0.056)\end{array}$ & $\begin{array}{c}0.02 \\
(0.053)\end{array}$ & $\begin{array}{c}0.05 \\
(0.066)\end{array}$ & $\begin{array}{l}0.031 \\
(0.07)\end{array}$ \\
\hline Higher Education & $\begin{array}{c}0.203 * * * \\
(0.055)\end{array}$ & $\begin{array}{c}0.282^{* * *} \\
(0.098)\end{array}$ & $\begin{array}{c}0.191^{* * *} \\
(0.059)\end{array}$ & $\begin{array}{c}0.222^{* * *} \\
(0.06)\end{array}$ & $\begin{array}{c}0.193 * * * \\
(0.067)\end{array}$ & $\begin{array}{c}0.196^{* * *} \\
(0.056)\end{array}$ & & $\begin{array}{c}0.223 * * * \\
(0.056)\end{array}$ & $\begin{array}{c}0.227 * * * \\
(0.079)\end{array}$ \\
\hline Retired & $\begin{array}{c}0.069 \\
(0.055)\end{array}$ & $\begin{array}{c}0.083 \\
(0.072)\end{array}$ & $\begin{array}{l}-0.375 \\
(0.228)\end{array}$ & $\begin{array}{c}0.037 \\
(0.085)\end{array}$ & $\begin{array}{c}0.038 \\
(0.062)\end{array}$ & $\begin{array}{c}0.077 \\
(0.055)\end{array}$ & $\begin{array}{c}0.063 \\
(0.056)\end{array}$ & $\begin{array}{c}0.16^{*} \\
(0.084)\end{array}$ & $\begin{array}{l}-0.001 \\
(0.067)\end{array}$ \\
\hline Home & $\begin{array}{c}0.05 \\
(0.043)\end{array}$ & $\begin{array}{c}0.062 \\
(0.061)\end{array}$ & $\begin{array}{c}0.046 \\
(0.047)\end{array}$ & $\begin{array}{c}0.07 \\
(0.187)\end{array}$ & $\begin{array}{c}0.038 \\
(0.042)\end{array}$ & $\begin{array}{c}0.065 \\
(0.042)\end{array}$ & $\begin{array}{c}0.047 \\
(0.044)\end{array}$ & $\begin{array}{l}0.17^{* * *} \\
(0.052)\end{array}$ & $\begin{array}{l}-0.044 \\
(0.059)\end{array}$ \\
\hline School & $\begin{array}{c}0.154^{* * *} \\
(0.054) \\
\end{array}$ & $\begin{array}{l}-0.405^{*} \\
(0.227) \\
\end{array}$ & $\begin{array}{l}0.093^{*} \\
(0.053) \\
\end{array}$ & $\begin{array}{c}0.127 \\
(0.082) \\
\end{array}$ & $\begin{array}{c}0.189^{* * * *} \\
(0.072)\end{array}$ & $\begin{array}{c}0.165^{* * *} \\
(0.059) \\
\end{array}$ & $\begin{array}{c}0.108^{*} \\
(0.062)\end{array}$ & $\begin{array}{c}0.012 \\
(0.078) \\
\end{array}$ & $\begin{array}{c}0.243^{* * *} \\
(0.079) \\
\end{array}$ \\
\hline $\begin{array}{l}\text { Number of Obs. } \\
\text { Pseudo-R2 }\end{array}$ & $\begin{array}{l}36,599 \\
0.0808\end{array}$ & $\begin{array}{l}13,943 \\
0.0801\end{array}$ & $\begin{array}{l}22,656 \\
0.0855\end{array}$ & $\begin{array}{l}18,059 \\
0.0793\end{array}$ & $\begin{array}{l}18,540 \\
0.0851\end{array}$ & $\begin{array}{l}34,939 \\
0.0766\end{array}$ & $\begin{array}{l}27,875 \\
0.0714\end{array}$ & $\begin{array}{l}16,472 \\
0.0861\end{array}$ & $\begin{array}{l}20,127 \\
0.073\end{array}$ \\
\hline $\begin{array}{l}\text { Year Effects } \\
\text { Country Effects }\end{array}$ & $\begin{array}{l}\text { Yes } \\
\text { Yes }\end{array}$ & $\begin{array}{l}\text { Yes } \\
\text { Yes }\end{array}$ & $\begin{array}{l}\text { Yes } \\
\text { Yes }\end{array}$ & $\begin{array}{l}\text { Yes } \\
\text { Yes }\end{array}$ & $\begin{array}{l}\text { Yes } \\
\text { Yes }\end{array}$ & $\begin{array}{l}\text { Yes } \\
\text { Yes }\end{array}$ & $\begin{array}{l}\text { Yes } \\
\text { Yes }\end{array}$ & $\begin{array}{l}\text { Yes } \\
\text { Yes }\end{array}$ & $\begin{array}{l}\text { Yes } \\
\text { Yes }\end{array}$ \\
\hline
\end{tabular}

Notes: Regressions are Ordered Logits. The dependent variable is ‘self-reported satisfaction' . *, ** and *** indicate significance at the $10 \%, 5 \%$ and $1 \%$ level. Clustered standard errors are reported in parenthesis. 
Model 5 refers to the collective effect of the World and European football cups.

Model 5: World \& Euro Cups

\begin{tabular}{|c|c|c|c|c|c|c|c|c|c|}
\hline Restrictions & None & Aged $\geq 50$ & Aged $<50$ & Males & Females & Employed & $\begin{array}{l}\text { No Higher } \\
\text { Education }\end{array}$ & $\begin{array}{l}\text { In Upper } \\
\text { Income }\end{array}$ & $\begin{array}{c}\text { Not in } \\
\text { Upper Inc. }\end{array}$ \\
\hline \multicolumn{10}{|l|}{ Sport Variables } \\
\hline \multirow[t]{2}{*}{ (RankPost-RankPre) } & 0.017 & 0.012 & 0.021 & 0.017 & 0.016 & 0.017 & 0.013 & 0.017 & 0.017 \\
\hline & (0.011) & $(0.009)$ & $(0.013)$ & $(0.012)$ & $(0.011)$ & $(0.011)$ & (0.011) & $(0.011)$ & $(0.012)$ \\
\hline \multirow[t]{2}{*}{ Host } & $0.315^{* *}$ & $0.415^{* *}$ & $0.258^{*}$ & $0.40^{* * *}$ & 0.245 & $0.298^{*}$ & $0.348^{* *}$ & $0.295^{* *}$ & $0.311^{*}$ \\
\hline & $(0.152)$ & $(0.162)$ & (0.149) & $(0.148)$ & $(0.16)$ & $(0.152)$ & $(0.158)$ & $(0.143)$ & $(0.162)$ \\
\hline \multicolumn{10}{|l|}{ Macro Variables } \\
\hline \multirow{2}{*}{ GDP p.c. } & $0.0002^{* * *}$ & $0.0002^{* * *}$ & $0.0002^{* * *}$ & $0.0002^{* * *}$ & $0.0002^{* * *}$ & $0.0002^{* * *}$ & $0.0002 * * *$ & $0.0002^{* * *}$ & $0.0003^{* * *}$ \\
\hline & $(0.0001)$ & $(0.0001)$ & $(0.0001)$ & $(0.0001)$ & $(0.0001)$ & $(0.0001)$ & $(0.0001)$ & $(0.0001)$ & $(0.0001)$ \\
\hline \multirow[t]{2}{*}{ Unemployment } & -1.324 & -0.046 & -2.216 & -1.265 & -1.181 & -0.905 & -1.324 & 0.735 & -2.365 \\
\hline & (2.171) & (2.353) & $(2.127)$ & (2.121) & $(2.316)$ & $(2.21)$ & (2.241) & $(2.20)$ & $(2.213)$ \\
\hline \multirow[t]{2}{*}{ Inflation } & $-9.029 * * *$ & $-6.15^{* * *}$ & $-11.007 * * *$ & $-10.501^{* * *}$ & $-7.644 * * *$ & $-8.546^{* * *}$ & $-9.176^{* * *}$ & $-8.961 * * *$ & $-9.227 * * *$ \\
\hline & $(2.056)$ & $(2.116)$ & $(2.124)$ & (1.951) & $(2.236)$ & $(2.037)$ & $(2.134)$ & $(2.04)$ & (2.379) \\
\hline \multicolumn{10}{|l|}{ Personal Controls } \\
\hline \multirow{2}{*}{ Unemployed } & $-0.942^{* * *}$ & $-0.763^{* * *}$ & $-1.019^{* * *}$ & $-1.194 * * *$ & $-0.72 * * *$ & & $-1.003^{* * *}$ & $-0.733^{* * *}$ & $-1.032^{* * *}$ \\
\hline & $(0.073)$ & $(0.115)$ & $(0.08)$ & $(0.086)$ & $(0.091)$ & & $(0.078)$ & $(0.10)$ & $(0.071)$ \\
\hline \multirow[t]{2}{*}{ Self employed } & 0.039 & 0.054 & 0.04 & 0.012 & $0.065^{\prime}$ & 0.04 & $0.015^{\prime}$ & 0.066 & 0.009 \\
\hline & $(0.039)$ & $(0.075)$ & $(0.049)$ & $(0.046)$ & $(0.06)$ & $(0.04)$ & $(0.05)$ & $(0.045)$ & $(0.072)$ \\
\hline \multirow{2}{*}{ Male } & $-0.106^{* * *}$ & -0.028 & $-0.146^{* * *}$ & & & $-0.075^{* * *}$ & $-0.07^{* *}$ & $-0.139 * * *$ & $-0.069 * *$ \\
\hline & $(0.028)$ & $(0.043)$ & $(0.035)$ & & & $(0.026)$ & $(0.027)$ & $(0.047)$ & $(0.035)$ \\
\hline \multirow[t]{2}{*}{ Married } & $0.287^{* * *}$ & $0.147^{*}$ & $0.371^{* * *}$ & $0.223^{* * *}$ & $0.338^{* * *}$ & $0.277^{*} * *$ & $0.265^{* * *}$ & $0.346^{* * *}$ & $0.252^{* * *}$ \\
\hline & $(0.04)$ & $(0.086)$ & $(0.046)$ & $(0.052)$ & $(0.052)$ & $(0.04)$ & $(0.043)$ & $(0.051)$ & $(0.05)$ \\
\hline \multirow[t]{2}{*}{ Defacto Married } & -0.032 & $-0.251^{* *}$ & 0.021 & -0.049 & -0.016 & -0.023 & -0.095 & -0.005 & -0.037 \\
\hline & $(0.059)$ & $(0.118)$ & $(0.065)$ & $(0.075)$ & $(0.073)$ & $(0.064)$ & $(0.074)$ & $(0.077)$ & $(0.079)$ \\
\hline \multirow[t]{2}{*}{ Divorced } & $-0.417^{* * *}$ & $-0.503 * * *$ & $-0.347^{* * *}$ & $-0.223^{* *}$ & $-0.529 * * *$ & $-0.41^{* * *}$ & $-0.478^{* * *}$ & $-0.266^{* *}$ & $-0.442^{* * *}$ \\
\hline & $(0.08)$ & $(0.121)$ & $(0.088)$ & $(0.106)$ & $(0.099)$ & $(0.083)$ & $(0.09)$ & $(0.124)$ & $(0.083)$ \\
\hline \multirow[t]{2}{*}{ Separated } & $-0.427^{* * *}$ & $-0.633^{* * *}$ & $-0.324 * *$ & -0.10 & $-0.589^{* * *}$ & $-0.47^{* * *}$ & $-0.424 * * *$ & $-0.646^{* * *}$ & $-0.337^{* * *}$ \\
\hline & $(0.094)$ & (0.192) & $(0.131)$ & $(0.192)$ & $(0.095)$ & (0.111) & $(0.118)$ & $(0.21)$ & $(0.112)$ \\
\hline \multirow[t]{2}{*}{ Widowed } & $-0.254 * * *$ & $-0.328^{* * *}$ & -0.159 & $-0.266^{* * *}$ & $-0.18^{* *}$ & $-0.265^{* * *}$ & $-0.282^{* * *}$ & $-0.382^{* * *}$ & $-0.227^{* * *}$ \\
\hline & $(0.056)$ & $(0.089)$ & (0.159) & $(0.101)$ & $(0.069)$ & $(0.056)$ & $(0.064)$ & $(0.123)$ & $(0.061)$ \\
\hline Second Income Quar. & $0.162^{* * *}$ & $0.138^{* * *}$ & $0.186^{* * *}$ & $0.152^{* * *}$ & $0.157^{* * *} *$ & $0.151^{* * *}$ & $0.166^{* * *}$ & & $0.173^{* * *}$ \\
\hline & $(0.041)$ & $(0.051)$ & $(0.048)$ & $(0.052)$ & $(0.051)$ & $(0.043)$ & $(0.042)$ & & $(0.041)$ \\
\hline Third Income Quar. & $0.377^{* * *}$ & $0.328^{* * *}$ & $0.414^{* * *}$ & $0.365^{* * *}$ & $0.372^{* * *}$ & $0.355^{* * *}$ & $0.38^{* * *}$ & $-0.291^{* * *}$ & \\
\hline & $(0.041)$ & $(0.059)$ & $(0.046)$ & $(0.054)$ & $(0.053)$ & $(0.04)$ & $(0.046)$ & $(0.031)$ & \\
\hline Fourth Income Quar. & $0.639 * * *$ & $0.619 * * *$ & $0.679 * * *$ & $0.605^{* * *}$ & $0.657^{* * *}$ & $0.612 * * *$ & $0.657^{* * *}$ & & \\
\hline & $(0.042)$ & $(0.071)$ & $(0.045)$ & $(0.053)$ & $(0.054)$ & $(0.041)$ & $(0.045)$ & & \\
\hline Age & $-0.055^{* * *}$ & $0.077^{* *}$ & $-0.074 * * *$ & $-0.058^{* * *}$ & $-0.049 * * *$ & $-0.052^{* * *}$ & $-0.053^{* * *}$ & $-0.067 * * *$ & $-0.047^{* * *}$ \\
\hline & $(0.005)$ & $(0.03)$ & $(0.011)$ & $(0.007)$ & $(0.006)$ & $(0.005)$ & $(0.006)$ & $(0.009)$ & $(0.005)$ \\
\hline $\mathrm{Age}^{2}$ & $0.001^{* * *}$ & $-0.001 *$ & $0.001 * * *$ & $0.001^{* * *}$ & $0.001 * * *$ & $0.001 * * *$ & $0.001^{* * *}$ & $0.001^{* * *}$ & $0.001^{* * *}$ \\
\hline & $(0.0001)$ & $(0.0002)$ & $(0.0002)$ & $(0.0001)$ & $(0.0001)$ & $(0.0001)$ & $(0.0001)$ & $(0.0001)$ & $(0.0001)$ \\
\hline Lower Education & -0.022 & 0.02 & 0.008 & 0.016 & -0.054 & -0.012 & -0.008 & -0.023 & -0.036 \\
\hline & $(0.045)$ & $(0.053)$ & $(0.054)$ & $(0.053)$ & $(0.048)$ & $(0.045)$ & $(0.045)$ & $(0.051)$ & $(0.059)$ \\
\hline Secondary Education & 0.027 & 0.113 & 0.023 & 0.092 & -0.047 & 0.038 & 0.032 & 0.081 & 0.017 \\
\hline & $(0.05)$ & $(0.082)$ & $(0.058)$ & $(0.064)$ & $(0.052)$ & $(0.05)$ & $(0.048)$ & $(0.069)$ & $(0.067)$ \\
\hline Higher Education & $0.163^{* * *}$ & $0.183^{* * *}$ & $0.184 * * *$ & $0.18^{* * *}$ & $0.159 * * *$ & $0.155^{* * *}$ & & $0.146^{* * *}$ & $0.19 * * *$ \\
\hline & $(0.05)$ & $(0.068)$ & $(0.062)$ & $(0.058)$ & $(0.059)$ & $(0.052)$ & & $(0.055)$ & $(0.072)$ \\
\hline Retired & $0.109^{* *}$ & $0.134^{* *}$ & $-0.437^{\prime}$ & $0.166^{* *}$ & 0.006 & $0.12 * *$ & 0.086 & $0.149^{* *}$ & 0.054 \\
\hline & $(0.053)$ & $(0.067)$ & $(0.233)$ & $(0.077)$ & $(0.072)$ & $(0.054)$ & $(0.053)$ & $(0.074)$ & $(0.063)$ \\
\hline Home & 0.031 & 0.082 & 0.011 & -0.072 & 0.0001 & 0.05 & 0.053 & $0.125^{* *}$ & -0.043 \\
\hline & $(0.039)$ & $(0.058)$ & $(0.046)$ & $(0.187)$ & $(0.041)$ & $(0.04)$ & $(0.043)$ & $(0.053)$ & $(0.051)$ \\
\hline School & $0.176^{* * *}$ & -0.328 & $0.142 * *$ & $0.127 *$ & $0.228^{* * *}$ & $0.181^{* * *}$ & $0.173^{* *}$ & 0.057 & $0.232^{* * *}$ \\
\hline & $(0.063)$ & $(0.241)$ & $(0.071)$ & $(0.067)$ & $(0.074)$ & $(0.064)$ & $(0.067)$ & $(0.083)$ & $(0.082)$ \\
\hline Number of Obs. & 45,807 & 17,194 & 28,613 & 22,343 & 23,464 & 43,240 & 35,368 & 20,810 & 24,997 \\
\hline Pseudo-R2 & 0.0849 & 0.0834 & 0.0903 & 0.0817 & 0.0907 & 0.0797 & 0.0773 & 0.087 & 0.0751 \\
\hline Year Effects & Yes & Yes & Yes & Yes & Yes & Yes & Yes & Yes & Yes \\
\hline Country Effects & Yes & Yes & Yes & Yes & Yes & Yes & Yes & Yes & Yes \\
\hline
\end{tabular}

Notes: Regressions are Ordered Logits. The dependent variable is 'self-reported satisfaction' . ${ }^{*}, * *$ and $* * *$ indicate significance at the $10 \%, 5 \%$ and $1 \%$ level. Clustered standard errors are reported in parenthesis. 
Model 6 reports the Difference-in-Difference estimation for the case of Football

Model 6: World and Euro Cups - DiD

\begin{tabular}{|c|c|c|c|c|c|c|c|c|c|}
\hline Restrictions & None & Aged $\geq 50$ & Aged $<50$ & Males & Females & Employed & $\begin{array}{l}\text { No Higher } \\
\text { Education }\end{array}$ & $\begin{array}{c}\text { In Upper } \\
\text { Income }\end{array}$ & $\begin{array}{c}\text { Not in } \\
\text { Upper Inc. }\end{array}$ \\
\hline Host*After & $\begin{array}{c}0.366^{* * *} \\
(0.11)\end{array}$ & $\begin{array}{l}0.40^{* * *} \\
(0.128)\end{array}$ & $\begin{array}{c}0.35^{* * *} \\
(0.102)\end{array}$ & $\begin{array}{c}0.335^{* * *} \\
(0.112)\end{array}$ & $\begin{array}{c}0.406^{* * * *} \\
(0.126)\end{array}$ & $\begin{array}{c}0.354 * * * \\
(0.117)\end{array}$ & $\begin{array}{c}0.352^{* * *} \\
(0.117)\end{array}$ & $\begin{array}{c}0.321^{* *} \\
(0.139)\end{array}$ & $\begin{array}{c}0.383^{* * *} * \\
(0.082)\end{array}$ \\
\hline Host & $\begin{array}{l}-0.112 \\
(0.175)\end{array}$ & $\begin{array}{l}-0.065 \\
0.183)\end{array}$ & $\begin{array}{l}-0.135 \\
(0168)\end{array}$ & $\begin{array}{l}-0.023 \\
(0.172)\end{array}$ & $\begin{array}{l}-0.199 \\
(0.182)\end{array}$ & $\begin{array}{l}-0.116 \\
(0.171)\end{array}$ & $\begin{array}{l}-0.079 \\
(0.187)\end{array}$ & $\begin{array}{l}-0.095 \\
(0.189)\end{array}$ & $\begin{array}{l}-0.109 \\
(0.163)\end{array}$ \\
\hline After & $\begin{array}{c}-0.11 \\
(0.078)\end{array}$ & $\begin{array}{l}-0.063 \\
(0.083)\end{array}$ & $\begin{array}{l}-0.139 * \\
(0.082)\end{array}$ & $\begin{array}{l}-0.111 \\
(0.083)\end{array}$ & $\begin{array}{l}-0.112 \\
(0.078)\end{array}$ & $\begin{array}{c}-0.116 \\
(0.08)\end{array}$ & $\begin{array}{l}-0.081 \\
(0.072)\end{array}$ & $\begin{array}{c}-0.264 * * * \\
(0.098)\end{array}$ & $\begin{array}{l}-0.003 \\
(0.065)\end{array}$ \\
\hline Personal Controls & & & & & & & & & \\
\hline Unemployed & $\begin{array}{c}-0.969 * * * \\
(0.078)\end{array}$ & $\begin{array}{c}-0.862^{* * *} \\
(0.115)\end{array}$ & $\begin{array}{c}-1.04 * * * \\
(0.079)\end{array}$ & $\begin{array}{c}-1.165^{* * *} \\
(0.091)\end{array}$ & $\begin{array}{c}-0.784^{* * *} \\
(0.085)\end{array}$ & & $\begin{array}{c}-0.984^{* * *} \\
(0.08)\end{array}$ & $\begin{array}{c}-0.726^{* * *} \\
(0.107)\end{array}$ & $\begin{array}{c}-1.059 * * * \\
(0.08)\end{array}$ \\
\hline Self employed & $\begin{array}{c}0.043 \\
(0.046)\end{array}$ & $\begin{array}{c}0.092 \\
(0.068)\end{array}$ & $\begin{array}{c}0.02 \\
(0.055)\end{array}$ & $\begin{array}{c}0.049 \\
(0.046)\end{array}$ & $\begin{array}{c}0.009 \\
(0.063)\end{array}$ & $\begin{array}{c}0.037 \\
(0.045)\end{array}$ & $\begin{array}{c}0.067 \\
(0.054)\end{array}$ & $\begin{array}{c}0.031 \\
(0.047)\end{array}$ & $\begin{array}{c}0.049 \\
(0.065)\end{array}$ \\
\hline Male & $\begin{array}{c}-0.069 * * \\
(0.028)\end{array}$ & $\begin{array}{c}0.016 \\
(0.033)\end{array}$ & $\begin{array}{c}-0.113 * * * \\
(0.033)\end{array}$ & & & $\begin{array}{l}-0.044 \\
(0.027)\end{array}$ & $\begin{array}{l}-0.05^{*} \\
(0.028)\end{array}$ & $\begin{array}{l}-0.072^{*} \\
(0.038)\end{array}$ & $\begin{array}{c}-0.059^{*} \\
(0.033)\end{array}$ \\
\hline Married & $\begin{array}{c}0.262^{* * *} \\
(0.039)\end{array}$ & $\begin{array}{c}0.121^{*} \\
(0.068)\end{array}$ & $\begin{array}{c}0.359 * * * \\
(0.041)\end{array}$ & $\begin{array}{c}0.184^{* * *} \\
(0.047)\end{array}$ & $\begin{array}{c}0.321^{* * *} \\
(0.046)\end{array}$ & $\begin{array}{c}0.268 * * * \\
(0.041)\end{array}$ & $\begin{array}{c}0.23^{* * *} \\
(0.047)\end{array}$ & $\begin{array}{c}0.297 * * * \\
(0.046)\end{array}$ & $\begin{array}{l}0.24 * * * \\
(0.053)\end{array}$ \\
\hline Defacto Married & $\begin{array}{c}0.062 \\
(0.046)\end{array}$ & $\begin{array}{c}-0.265^{* * *} \\
(0.087)\end{array}$ & $\begin{array}{c}0.141^{* * *} \\
(0.05)\end{array}$ & $\begin{array}{l}0.045 \\
(0.064)\end{array}$ & $\begin{array}{c}0.075 \\
(0.058)\end{array}$ & $\begin{array}{c}0.075 \\
(0.047)\end{array}$ & $\begin{array}{c}0.052 \\
(0.056)\end{array}$ & $\begin{array}{c}0.072 \\
(0.069)\end{array}$ & $\begin{array}{c}0.064 \\
(0.062)\end{array}$ \\
\hline Divorced & $\begin{array}{c}-0.345^{* * *} \\
(0.054)\end{array}$ & $\begin{array}{c}-0.401^{* * *} \\
(0.087)\end{array}$ & $\begin{array}{c}-0.291^{* * *} \\
(0.065)\end{array}$ & $\begin{array}{c}-0.205^{* * *} \\
(0.078)\end{array}$ & $\begin{array}{c}-0.414^{* * *} \\
(0.077)\end{array}$ & $\begin{array}{c}-0.336^{* * *} \\
(0.052)\end{array}$ & $\begin{array}{c}-0.411^{* * * *} \\
(0.065)\end{array}$ & $\begin{array}{l}-0.148^{*} \\
(0.079)\end{array}$ & $\begin{array}{c}-0.385^{* * *} \\
(0.057)\end{array}$ \\
\hline Separated & $\begin{array}{c}-0.472^{* * *} \\
(0.079)\end{array}$ & $\begin{array}{c}-0.614^{* * *} \\
(0.165)\end{array}$ & $\begin{array}{c}-0.384^{* * *} \\
(0.112)\end{array}$ & $\begin{array}{c}-0.443 * * * \\
(0.152)\end{array}$ & $\begin{array}{c}-0.485^{* * *} \\
(0.09)\end{array}$ & $\begin{array}{c}-0.472^{* * *} \\
(0.085)\end{array}$ & $\begin{array}{c}-0.57 * * * \\
(0.092)\end{array}$ & $\begin{array}{l}-0.40^{* *} \\
(0.177)\end{array}$ & $\begin{array}{c}-0.479 * * * \\
(0.093)\end{array}$ \\
\hline Widowed & $\begin{array}{c}-0.195^{* * *} \\
(0.037)\end{array}$ & $\begin{array}{c}-0.234 * * * \\
(0.064)\end{array}$ & $\begin{array}{c}-0.278^{*} \\
(0.142)\end{array}$ & $\begin{array}{c}-0.293 * * * \\
(0.081)\end{array}$ & $\begin{array}{l}-0.068 \\
(0.048)\end{array}$ & $\begin{array}{c}-0.197 * * * \\
(0.037)\end{array}$ & $\begin{array}{c}-0.208^{* * *} \\
(0.045)\end{array}$ & $\begin{array}{l}-0.11 \\
(0.102)\end{array}$ & $\begin{array}{c}-0.188^{* * *} \\
(0.05)\end{array}$ \\
\hline Second Income Quar. & $\begin{array}{c}0.148 * * * \\
(0.043)\end{array}$ & $\begin{array}{c}0.142 * * * \\
(0.037)\end{array}$ & $\begin{array}{l}0.134 * * \\
(0.056)\end{array}$ & $\begin{array}{c}0.118^{* * *} \\
(0.04)\end{array}$ & $\begin{array}{c}0.157^{* * *} \\
(0.054)\end{array}$ & $\begin{array}{c}0.131^{* * *} \\
(0.042)\end{array}$ & $\begin{array}{c}0.153^{* * *} \\
(0.043)\end{array}$ & & $\begin{array}{c}0.165^{* * *} \\
(0.042)\end{array}$ \\
\hline Third Income Quar. & $\begin{array}{c}0.366^{* * *} \\
(0.044)\end{array}$ & $\begin{array}{c}0.371^{* * *} \\
(0.049)\end{array}$ & $\begin{array}{c}0.351^{* * *} \\
(0.054)\end{array}$ & $\begin{array}{c}0.332^{* * *} \\
(0.048)\end{array}$ & $\begin{array}{c}0.377^{* * *} \\
(0.049)\end{array}$ & $\begin{array}{c}0.342^{* * *} \\
(0.044)\end{array}$ & $\begin{array}{c}0.359 * * * \\
(0.045)\end{array}$ & $\begin{array}{c}0.309 * * * \\
(0.024)\end{array}$ & \\
\hline Fourth Income Quar. & $\begin{array}{c}0.631 * * * \\
(0.044)\end{array}$ & $\begin{array}{c}0.678^{* * *} \\
(0.059)\end{array}$ & $\begin{array}{c}0.614 * * * \\
(0.05)\end{array}$ & $\begin{array}{c}0.602^{* * *} \\
(0.046)\end{array}$ & $\begin{array}{c}0.643 * * * \\
(0.05)\end{array}$ & $\begin{array}{l}0.60^{* * *} \\
(0.043)\end{array}$ & $\begin{array}{c}0.622^{* * *} \\
(0.047)\end{array}$ & & \\
\hline Age & $\begin{array}{c}-0.051^{* * *} \\
(0.005)\end{array}$ & $\begin{array}{c}0.039 \\
(0.025)\end{array}$ & $\begin{array}{c}-0.086^{* * *} \\
(0.011)\end{array}$ & $\begin{array}{c}-0.054^{* * *} \\
(0.006)\end{array}$ & $\begin{array}{c}-0.047 * * * \\
(0.006)\end{array}$ & $\begin{array}{c}-0.049 * * * \\
(0.005)\end{array}$ & $\begin{array}{c}-0.049 * * * \\
(0.005)\end{array}$ & $\begin{array}{c}-0.059 * * * \\
(0.008)\end{array}$ & $\begin{array}{c}-0.048^{* * *} \\
(0.005)\end{array}$ \\
\hline $\mathrm{Age}^{2}$ & $\begin{array}{c}\mathbf{0 . 0 0 1 * * *} \\
\mathbf{( 0 . 0 0 0 1 )}\end{array}$ & $\begin{array}{c}-0.001 \\
(0.0002)\end{array}$ & $\begin{array}{c}0.001 * * * \\
(0.0002)\end{array}$ & $\begin{array}{l}0.001^{* * *} \\
(0.0001)\end{array}$ & $\begin{array}{l}0.001 * * * \\
(0.0001)\end{array}$ & $\begin{array}{c}0.001^{* * *} \\
(0.0001)\end{array}$ & $\begin{array}{l}0.001 * * * \\
(0.0001)\end{array}$ & $\begin{array}{c}0.001 * * * \\
(0.0001)\end{array}$ & $\begin{array}{c}0.001 * * * \\
(0.0001)\end{array}$ \\
\hline Lower Education & $\begin{array}{c}-0.02 \\
(0.051)\end{array}$ & $\begin{array}{c}0.029 \\
(0.063)\end{array}$ & $\begin{array}{l}0.051 \\
(0.06)\end{array}$ & $\begin{array}{l}-0.024 \\
(0.047)\end{array}$ & $\begin{array}{l}-0.018 \\
(0.063)\end{array}$ & $\begin{array}{l}-0.016 \\
(0.052)\end{array}$ & $\begin{array}{l}-0.007 \\
(0.049)\end{array}$ & $\begin{array}{c}0.006 \\
(0.059)\end{array}$ & $\begin{array}{l}-0.034 \\
(0.057)\end{array}$ \\
\hline Secondary Education & $\begin{array}{c}0.004 \\
(0.044)\end{array}$ & $\begin{array}{c}0.075 \\
(0.081)\end{array}$ & $\begin{array}{c}0.031 \\
(0.045)\end{array}$ & $\begin{array}{c}0.012 \\
(0.053)\end{array}$ & $\begin{array}{l}-0.008 \\
(0.052)\end{array}$ & $\begin{array}{c}0.019 \\
(0.043)\end{array}$ & $\begin{array}{c}0.032 \\
(0.039)\end{array}$ & $\begin{array}{c}0.01 \\
(0.053)\end{array}$ & $\begin{array}{c}0.037 \\
(0.052)\end{array}$ \\
\hline Higher Education & $\begin{array}{c}0.159 * * * \\
(0.051)\end{array}$ & $\begin{array}{l}0.192^{* *} \\
(0.083)\end{array}$ & $\begin{array}{c}0.213^{* * *} \\
(0.059)\end{array}$ & $\begin{array}{c}0.156^{* * *} \\
(0.058)\end{array}$ & $\begin{array}{c}0.169 * * * \\
(0.061)\end{array}$ & $\begin{array}{c}0.169 * * * \\
(0.052)\end{array}$ & & $\begin{array}{c}0.157^{* * *} \\
(0.06)\end{array}$ & $\begin{array}{c}0.176^{* * *} \\
(0.062)\end{array}$ \\
\hline Retired & $\begin{array}{c}0.037 \\
(0.041)\end{array}$ & $\begin{array}{c}0.061 \\
(0.048)\end{array}$ & $\begin{array}{c}-0.389^{* *} \\
(0.155)\end{array}$ & $\begin{array}{l}-0.008 \\
(0.057)\end{array}$ & $\begin{array}{l}-0.004 \\
(0.049)\end{array}$ & $\begin{array}{c}0.042 \\
(0.039)\end{array}$ & $\begin{array}{c}0.037 \\
(0.043)\end{array}$ & $\begin{array}{c}0.13^{*} \\
(0.073)\end{array}$ & $\begin{array}{l}-0.026 \\
(0.052)\end{array}$ \\
\hline Home & $\begin{array}{c}0.026 \\
(0.035)\end{array}$ & $\begin{array}{l}0.033 \\
(0.05)\end{array}$ & $\begin{array}{c}0.041 \\
(0.039)\end{array}$ & $\begin{array}{c}0.12 \\
(0.208)\end{array}$ & $\begin{array}{c}0.001 \\
(0.035)\end{array}$ & $\begin{array}{c}0.035 \\
(0.036)\end{array}$ & $\begin{array}{l}0.038 \\
(0.04)\end{array}$ & $\begin{array}{c}0.187^{* * *} \\
(0.047)\end{array}$ & $\begin{array}{l}-0.068 \\
(0.048)\end{array}$ \\
\hline School & $\begin{array}{c}0.256^{* * *} \\
(0.055)\end{array}$ & $\begin{array}{l}-0.246 \\
(0.292)\end{array}$ & $\begin{array}{c}0.211 * * * \\
(0.059)\end{array}$ & $\begin{array}{c}0.254^{* * *} \\
(0.063)\end{array}$ & $\begin{array}{c}0.262^{* * *} * \\
(0.068)\end{array}$ & $\begin{array}{c}0.274 * * * \\
(0.056)\end{array}$ & $\begin{array}{c}0.241^{* * *} \\
(0.056)\end{array}$ & $\begin{array}{c}0.131^{*} \\
(0.068)\end{array}$ & $\begin{array}{c}0.322^{* * *} \\
(0.067)\end{array}$ \\
\hline $\begin{array}{l}\text { Number of Obs. } \\
\text { Pseudo-R2 }\end{array}$ & $\begin{array}{l}67,476 \\
0.0819\end{array}$ & $\begin{array}{l}24,977 \\
0.0826\end{array}$ & $\begin{array}{l}42,499 \\
0.0851\end{array}$ & $\begin{array}{l}32,892 \\
0.0793\end{array}$ & $\begin{array}{l}34,584 \\
0.0865\end{array}$ & $\begin{array}{l}63,749 \\
0.0777\end{array}$ & $\begin{array}{l}52,170 \\
0.0737\end{array}$ & $\begin{array}{l}29,575 \\
0.0858\end{array}$ & $\begin{array}{l}37,901 \\
0.0717\end{array}$ \\
\hline $\begin{array}{l}\text { Year Effects } \\
\text { Country Effects }\end{array}$ & $\begin{array}{l}\text { Yes } \\
\text { Yes }\end{array}$ & $\begin{array}{l}\text { Yes } \\
\text { Yes }\end{array}$ & $\begin{array}{l}\text { Yes } \\
\text { Yes }\end{array}$ & $\begin{array}{l}\text { Yes } \\
\text { Yes }\end{array}$ & $\begin{array}{l}\text { Yes } \\
\text { Yes }\end{array}$ & $\begin{array}{l}\text { Yes } \\
\text { Yes }\end{array}$ & $\begin{array}{l}\text { Yes } \\
\text { Yes }\end{array}$ & $\begin{array}{l}\text { Yes } \\
\text { Yes }\end{array}$ & $\begin{array}{l}\text { Yes } \\
\text { Yes }\end{array}$ \\
\hline
\end{tabular}

Notes: Regressions are Ordered Logits run over the Years: 1984, 1988, 1990 and 2000. The dependent variable is 'self-reported satisfaction'.

$*, * *$ and $* * *$ indicate significance at the $10 \%, 5 \%$ and $1 \%$ level. Clustered standard errors are reported in parenthesis. 


\section{Appendix C: Marginal Effects}

As the sign of the estimated coefficients in the ordered logit models does not unambiguously determine the direction of the effect for intermediate life satisfaction outcomes, marginal effects (ME) have to be evaluated (Wooldridge, 2002). These are evaluated at the means for continuous variables and for binary variables it is the difference between the response probabilities when the variable takes the value of one and that of zero (Greene, 2003). For illustration purposes we only evaluate ME on the overall sample for each of our six models. Full results on the ME of the remaining variables were of the expected sign and are available from the authors upon request.

Model 1: Olympic Games

\begin{tabular}{lcccc}
\hline \multirow{3}{*}{ (Actual-Predicted $)$} & $\operatorname{Pr}($ Happy $=0)=0.032$ & $\operatorname{Pr}($ Happy=1)=0.146 & $\operatorname{Pr}($ Happy=2)=0.604 & $\operatorname{Pr}($ Happy=3)=0.218 \\
\cline { 2 - 5 } & -0.001 & -0.001 & -0.001 & 0.001 \\
Host & $(0.0002)$ & $(0.001)$ & $(0.001)$ & $(0.001)$ \\
& 0.004 & 0.014 & $\mathbf{0 . 0 0 2 * *}$ & -0.02 \\
& $(0.004)$ & $(0.013)$ & $\mathbf{( 0 . 0 0 1 )}$ & $(0.017)$
\end{tabular}

Model 2: Olympic Games Excluding 1984

\begin{tabular}{lcccc}
\hline \multirow{3}{*}{ (Actual-Predicted $)$} & $\operatorname{Pr}($ Happy $=0)=0.033$ & $\operatorname{Pr}($ Happy=1)=0.15 & $\operatorname{Pr}($ Happy=2)=0.599 & $\operatorname{Pr}(\operatorname{Happy}=3)=0.218$ \\
\cline { 2 - 4 } & -0.001 & -0.002 & -0.001 & 0.002 \\
Host & $(0.001)$ & $(0.001)$ & $(0.001)$ & $(0.002)$ \\
& 0.004 & 0.016 & 0.001 & -0.021 \\
& $(0.004)$ & $(0.016)$ & $(0.001)$ & $(0.02)$
\end{tabular}

Model 3: Olympic Games

\begin{tabular}{lcccc}
\hline \multirow{3}{*}{ (Actual-Actual Lagged $)$} & $\operatorname{Pr}(\operatorname{Happy}=0)=0.032$ & $\operatorname{Pr}(\operatorname{Happy}=1)=0.144$ & $\operatorname{Pr}(\operatorname{Happy}=2)=0.606$ & $\operatorname{Pr}(\operatorname{Hap} p y=3)=0.218$ \\
\cline { 2 - 5 } & -0.001 & -0.001 & -0.001 & 0.001 \\
Host & $(0.001)$ & $(0.001)$ & $(0.001)$ & $(0.001)$ \\
& 0.005 & 0.019 & 0.002 & -0.254 \\
& $(0.004)$ & $(0.015)$ & $(0.001)$ & $(0.019)$
\end{tabular}

Model 4: Olympic Games Excluding 1984

\begin{tabular}{|c|c|c|c|c|}
\hline \multirow{3}{*}{ (Actual-Actual Lagged) } & $\operatorname{Pr}($ Happy $=0)=0.032$ & $\operatorname{Pr}($ Happy $=1)=0.149$ & $\operatorname{Pr}($ Happy $=2)=0.601$ & $\operatorname{Pr}($ Happy $=3)=0.218$ \\
\hline & $-0.001^{* *}$ & $-0.001^{* *}$ & $-0.001^{*}$ & $0.001^{* *}$ \\
\hline & $(0.0001)$ & $(0.0005)$ & $(0.0001)$ & $(0.0007)$ \\
\hline \multirow[t]{2}{*}{ Host } & $0.009 *$ & $0.033^{*}$ & -0.001 & $-0.042^{* *}$ \\
\hline & (0.005) & $(0.018)$ & (0.005) & $(0.02)$ \\
\hline
\end{tabular}

Model 5: World \& Euro Cup - Difference in Ranking Position and Host

\begin{tabular}{lcccc}
\hline \multirow{3}{*}{ RankPost-RankPre $)$} & $\operatorname{Pr}(\operatorname{Happy}=0)=0.03$ & $\operatorname{Pr}(\operatorname{Happy}=1)=0.134$ & $\operatorname{Pr}(\operatorname{Happy}=2)=0.629$ & $\operatorname{Pr}(\operatorname{Happy}=3)=0.207$ \\
\cline { 2 - 5 } & -0.001 & -0.002 & -0.001 & 0.003 \\
Host & $(0.0003)$ & $(0.001)$ & $(0.0003)$ & $(0.002)$ \\
& $\mathbf{- 0 . 0 0 8 * *}$ & $\mathbf{- 0 . 0 3 1 * *}$ & -0.016 & $\mathbf{0 . 0 5 6}$ \\
& $\mathbf{( 0 . 0 0 3 )}$ & $\mathbf{( 0 . 0 1 4 )}$ & $(0.012)$ & $\mathbf{( 0 . 0 2 9 )}$
\end{tabular}

Model 6: World and Euro Cup - DiD

\begin{tabular}{|c|c|c|c|c|}
\hline & $\operatorname{Pr}($ Happy $=0)=0.035$ & $\operatorname{Pr}($ Happy $=1)=0.14$ & $\operatorname{Pr}($ Happy $=2)=0.606$ & $\operatorname{Pr}($ Happy $=3)=0.219$ \\
\hline Host*After & $\begin{array}{c}-0.011 * * * \\
(0.003)\end{array}$ & $\begin{array}{c}-0.037^{* * *} \\
(0.01)\end{array}$ & $\begin{array}{c}-0.021^{* *} \\
(0.09)\end{array}$ & $\begin{array}{c}0.068^{* * *} \\
(0.022)\end{array}$ \\
\hline
\end{tabular}




\section{Appendix D: Announcement and Legacy Effects ${ }^{23}$}

\begin{tabular}{|c|c|c|c|c|c|c|c|c|}
\hline & \multicolumn{4}{|c|}{ Announcement Effects } & & \multicolumn{3}{|c|}{ Legacy Effects } \\
\hline \multicolumn{9}{|l|}{ Subgroup } \\
\hline \multicolumn{9}{|c|}{ FOOTBALL ONLY: 3 WCs, 7 EUROs } \\
\hline & FootHost6yb & FootHost 4yb & FootHost2yb & FootHost1yb & & FootHost1ya & FootHost2ya & FootHost4ya \\
\hline \multirow[t]{2}{*}{ All } & $-0.10^{* * * *}$ & $-0.063^{*}$ & -0.023 & -0.028 & $\mathbf{E}$ & 0.033 & 0.026 & 0.055 \\
\hline & $(0.032)$ & $(0.037)$ & $(0.045)$ & $(0.056)$ & & $(0.055)$ & $(0.046)$ & $(0.036)$ \\
\hline \multirow[t]{2}{*}{$>50$} & $-0.057^{*}$ & -0.031 & -0.014 & -0.021 & & 0.042 & 0.034 & 0.043 \\
\hline & $(0.033)$ & $(0.036)$ & $(0.044)$ & $(0.058)$ & $\mathbf{V}$ & $(0.055)$ & $(0.046)$ & $(0.036)$ \\
\hline \multirow[t]{2}{*}{$<50$} & $-0.12 * * *$ & $-0.076^{*}$ & -0.018 & -0.023 & & 0.033 & 0.023 & 0.064 \\
\hline & $(0.034)$ & $(0.04)$ & $(0.048)$ & $(0.059)$ & & $(0.059)$ & $(0.05)$ & $(0.039)$ \\
\hline \multirow[t]{2}{*}{ Male } & $-0.099 * * *$ & -0.061 & -0.005 & 0.006 & $\mathbf{E}$ & 0.065 & 0.06 & $0.087^{* *}$ \\
\hline & $(\mathbf{0 . 0 3 5 )}$ & $(0.041)$ & $(0.048)$ & $(0.058)$ & & $(0.053)$ & $(0.046)$ & $(0.036)$ \\
\hline \multirow[t]{2}{*}{ Female } & $-0.099 * * *$ & $-0.063^{*}$ & -0.037 & -0.057 & & 0.005 & -0.004 & 0.028 \\
\hline & $(0.032)$ & $(0.036)$ & $(0.045)$ & $(0.058)$ & $\mathbf{N}$ & $(0.06)$ & $(0.05)$ & $(0.038)$ \\
\hline \multirow[t]{2}{*}{ Dun } & $-0.104^{* * *}$ & $-0.067^{*}$ & -0.032 & -0.043 & & 0.023 & 0.015 & 0.045 \\
\hline & $(0.032)$ & $(0.036)$ & $(0.044)$ & $(0.056)$ & & $(0.055)$ & $(0.046)$ & $(0.036)$ \\
\hline \multirow[t]{2}{*}{ Hedu } & $-0.10^{* * *}$ & $-0.066^{*}$ & -0.03 & -0.025 & $\mathbf{T}$ & 0.032 & 0.029 & $0.06^{*}$ \\
\hline & $(0.034)$ & $\begin{array}{l}(0.038) \\
\end{array}$ & $(0.046)$ & $(0.057)$ & & $(0.054)$ & $(0.046)$ & $(0.036)$ \\
\hline \multicolumn{9}{|c|}{ OLYMPICS: 2 OLYMPICS (Only one Legacy observation exists for Greece, i.e. 2004, since our sample ends in 2004) } \\
\hline & olyHostoyb & olyHost4yb & olyHost2yb & olyHost1yb & & olyHost1ya & olyHost2ya & olyHost4ya \\
\hline \multirow[t]{2}{*}{ All } & 0.074 & 0.018 & 0.029 & 0.055 & $\mathbf{E}$ & -0.096 & $-0.217^{* *}$ & $-0.294^{* * *}$ \\
\hline & $(0.068)$ & $(0.064)$ & $(0.057)$ & $(0.061)$ & & $(0.094)$ & $(0.102)$ & $(0.068)$ \\
\hline \multirow[t]{2}{*}{$>50$} & 0.064 & 0.011 & 0.029 & 0.056 & & -0.017 & -0.123 & $-0.267 * * *$ \\
\hline & $(0.069)$ & $(0.066)$ & $(0.067)$ & $(0.069)$ & $\mathbf{V}$ & $(0.078)$ & $(0.094)$ & $(0.066)$ \\
\hline \multirow[t]{2}{*}{$<50$} & 0.084 & 0.03 & 0.039 & 0.06 & & -0.145 & $-0.276^{* *}$ & $-0.312^{* * *}$ \\
\hline & $(0.072)$ & $(0.069)$ & $(0.063)$ & $(0.069)$ & & $(0.112)$ & $(0.113)$ & $(0.08)$ \\
\hline \multirow[t]{2}{*}{ Male } & 0.064 & -0.002 & -0.01 & 0.014 & $\mathbf{E}$ & -0.121 & $-0.224 * *$ & $-0.268^{* * *}$ \\
\hline & $(0.066)$ & $(0.063)$ & $(0.057)$ & $(0.06)$ & & $(0.088)$ & $(0.092)$ & $(0.066)$ \\
\hline \multirow[t]{2}{*}{ Female } & 0.079 & 0.032 & 0.057 & 0.086 & & -0.074 & $-0.207^{*}$ & $-0.317^{* * *}$ \\
\hline & $(0.076)$ & $(0.071)$ & $(0.065)$ & $(0.069)$ & $\mathbf{N}$ & $(0.108)$ & $(0.115)$ & $\begin{array}{l}(0.078) \\
\end{array}$ \\
\hline \multirow[t]{2}{*}{ Dun } & 0.072 & 0.021 & 0.036 & 0.067 & & -0.10 & $-0.215^{* *}$ & $-0.289 * * *$ \\
\hline & $(0.07)$ & $(0.066)$ & $(0.059)$ & $(0.061)$ & & $(0.102)$ & $(0.104)$ & $(0.067)$ \\
\hline \multirow[t]{2}{*}{ Hedu } & 0.063 & 0.004 & 0.022 & 0.053 & $T$ & -0.072 & $-0.20^{*}$ & $-0.276^{* * *}$ \\
\hline & $(0.068)$ & $(0.064)$ & $(0.06)$ & $(0.065)$ & & $(0.095)$ & $(0.105)$ & $(0.068)$ \\
\hline \multicolumn{9}{|c|}{ OVERALL HOST: 3 WCs, 7 EUROs, 2 OLYMPICS } \\
\hline & Host tyb & Host $4 y b$ & Host2yb & Host1yb & & Host1ya & Host2ya & Host4ya \\
\hline All & $-0.07^{* *}$ & -0.048 & -0.015 & -0.014 & $E$ & 0.015 & -0.009 & 0.001 \\
\hline & $(0.029)$ & $(0.031)$ & $(0.038)$ & $(0.046)$ & & $(0.05)$ & $(0.045)$ & $(0.036)$ \\
\hline$>50$ & -0.036 & -0.023 & -0.007 & -0.007 & & 0.033 & 0.012 & -0.006 \\
\hline & $(0.029)$ & $(0.031)$ & $(0.038)$ & $(0.048)$ & $\mathbf{V}$ & $(0.048)$ & $(0.043)$ & $(0.036)$ \\
\hline$<50$ & $-0.085^{* * *}$ & $-0.057^{*}$ & -0.009 & -0.01 & & 0.008 & -0.019 & 0.005 \\
\hline & $(0.03)$ & $(0.033)$ & $(0.041)$ & $(0.049)$ & & $(0.055)$ & $(0.049)$ & $(0.039)$ \\
\hline Male & $-0.07^{* *}$ & -0.05 & -0.006 & 0.008 & $\mathbf{E}$ & 0.039 & 0.02 & 0.031 \\
\hline & $(0.03)$ & $(0.034)$ & $(0.041)$ & $(0.048)$ & & $(0.049)$ & $(0.045)$ & $(0.036)$ \\
\hline Female & $-0.069 * *$ & -0.046 & -0.023 & -0.033 & & -0.006 & -0.033 & -0.027 \\
\hline & $(0.029)$ & $(0.031)$ & $(0.038)$ & $(0.048)$ & $\mathbf{N}$ & $(0.054)$ & $(0.048)$ & $(0.039)$ \\
\hline Dun & $-0.073^{* *}$ & -0.051 & -0.021 & -0.024 & & 0.006 & -0.016 & -0.007 \\
\hline & (0.028) & $(0.031)$ & $(0.038)$ & $(0.046)$ & & $(0.05)$ & $(0.045)$ & $(0.035)$ \\
\hline Hedu & $-0.071^{* *}$ & -0.052 & -0.022 & -0.012 & $\mathbf{T}$ & 0.017 & -0.003 & 0.006 \\
\hline & $(0.03)$ & $(0.032)$ & $(0.039)$ & $(0.047)$ & & $(0.048)$ & $(0.045)$ & $(0.036)$ \\
\hline
\end{tabular}

${ }^{23}$ Detailed results on the remaining control variables are available from the authors upon request. 


\begin{tabular}{|c|c|c|c|c|c|c|c|c|}
\hline & \multicolumn{4}{|c|}{ Announcement Effects } & & \multicolumn{3}{|c|}{ Legacy Effects } \\
\hline \multicolumn{9}{|c|}{ WORLD CUP: 3 WCs } \\
\hline & wcHost6yb & wcHost4yb & wcHost2yb & wcHost $\mathbf{1} b$ & & wcHost1ya & wcHost2ya & wcHost4ya \\
\hline \multirow[t]{2}{*}{ All } & 0.007 & 0.057 & 0.079 & $0.119 *$ & $\mathbf{E}$ & $0.199 * *$ & $0.193^{* *}$ & $0.225^{* * *}$ \\
\hline & $(0.047)$ & $(0.049)$ & $(0.064)$ & $(0.065)$ & & $(0.081)$ & $(0.079)$ & $(0.048)$ \\
\hline \multirow[t]{2}{*}{$>50$} & 0.011 & 0.051 & 0.051 & 0.071 & & 0.108 & $0.109 *$ & $0.153^{* * *}$ \\
\hline & $(0.044)$ & $(0.045)$ & $(0.054)$ & $(0.053)$ & $\mathbf{V}$ & $(0.071)$ & $(0.06)$ & $(0.041)$ \\
\hline \multirow[t]{2}{*}{$<50$} & 0.009 & 0.066 & 0.105 & $0.156^{* *}$ & & $0.255^{* * *}$ & $0.246^{* * *}$ & $0.269 * * *$ \\
\hline & $(0.053)$ & $(0.056)$ & $(0.071)$ & $(0.076)$ & & $(0.093)$ & $(0.092)$ & $(0.056)$ \\
\hline \multirow[t]{2}{*}{ Male } & 0.01 & 0.067 & 0.091 & $0.134 *$ & $\mathbf{E}$ & $0.273^{*}$ & $0.235^{* * *}$ & $0.265^{* * *}$ \\
\hline & $(0.051)$ & $(0.054)$ & $(0.07)$ & $(0.07)$ & & $(0.082)$ & $(0.08)$ & $(0.05)$ \\
\hline \multirow[t]{2}{*}{ Female } & 0.005 & 0.049 & 0.07 & 0.107 & & 0.139 & $0.158^{*}$ & $0.197 * * *$ \\
\hline & $(0.046)$ & $(0.047)$ & $(0.061)$ & $(0.072)$ & $\mathbf{N}$ & $(0.097)$ & $(0.089)$ & $(0.052)$ \\
\hline \multirow[t]{2}{*}{ Dun } & 0.017 & 0.066 & 0.089 & $0.117^{*}$ & & $0.207^{* * *}$ & $0.196^{* *}$ & $0.221 * * *$ \\
\hline & $(0.046)$ & $(0.047)$ & $(0.06)$ & $(0.064)$ & & $(0.078)$ & $(0.079)$ & $(0.049)$ \\
\hline \multirow[t]{2}{*}{ Hedu } & 0.015 & 0.059 & 0.073 & $0.13^{* *}$ & $\mathbf{T}$ & $0.215^{* * *}$ & $0.215^{* * *}$ & $0.243^{* * *}$ \\
\hline & $(0.049)$ & $(0.052)$ & $(0.067)$ & $(0.059)$ & & $(0.072)$ & $(0.077)$ & $(0.048)$ \\
\hline \multicolumn{9}{|c|}{ EURO: 7 EUROs } \\
\hline & euHostgyb & euHost4yb & euHost2yb & euHostyb & & euHost1ya & euHost2ya & euHost4ya \\
\hline \multirow[t]{2}{*}{ All } & $-0.117^{* * *}$ & $-0.097^{* *}$ & -0.065 & -0.076 & $\mathbf{E}$ & 0.003 & -0.012 & -0.007 \\
\hline & $(0.036)$ & $(0.043)$ & $(0.054)$ & $(0.067)$ & & $(0.061)$ & $(0.051)$ & $(0.039)$ \\
\hline \multirow[t]{2}{*}{$>50$} & $-0.07^{*}$ & -0.055 & -0.039 & -0.048 & & 0.031 & 0.017 & 0.001 \\
\hline & $(0.038)$ & $(0.043)$ & $(0.056)$ & $(0.074)$ & $\mathbf{V}$ & $(0.063)$ & $(0.053)$ & $(0.042)$ \\
\hline \multirow[t]{2}{*}{$<50$} & $-0.141^{* * *}$ & $-0.117^{* * *}$ & -0.071 & -0.084 & & -0.008 & -0.027 & -0.012 \\
\hline & $(0.037)$ & $(0.045)$ & $(0.055)$ & $(0.065)$ & & $(0.064)$ & $(0.053)$ & $(0.041)$ \\
\hline \multirow[t]{2}{*}{ Male } & $-0.117^{* * *}$ & $-0.099 * *$ & -0.047 & -0.036 & $\mathbf{E}$ & 0.03 & 0.019 & 0.019 \\
\hline & $(0.04)$ & $(0.048)$ & $(0.058)$ & $(0.07)$ & & $(0.058)$ & $(0.05)$ & $(0.038)$ \\
\hline \multirow[t]{2}{*}{ Female } & $-0.116^{* * *}$ & $-0.094^{* *}$ & -0.079 & -0.111 & & -0.019 & -0.039 & -0.033 \\
\hline & $(0.035)$ & $\begin{array}{l}(0.041) \\
\end{array}$ & $(0.054)$ & $(0.068)$ & $\mathbf{N}$ & $\begin{array}{l}(0.068) \\
\end{array}$ & $(0.055)$ & $(0.043)$ \\
\hline \multirow[t]{2}{*}{ Dun } & $-0.125^{* * *}$ & $-0.105^{* *}$ & -0.08 & -0.095 & & -0.009 & -0.025 & -0.019 \\
\hline & $\begin{array}{l}(0.035) \\
\end{array}$ & $(0.042)$ & $(0.053)$ & $(0.066)$ & & $(0.061)$ & $(0.05)$ & $(0.038)$ \\
\hline \multirow[t]{2}{*}{ Hedu } & $-0.118^{* * *}$ & $-0.099 * *$ & -0.068 & -0.073 & $\mathbf{T}$ & 0.001 & -0.01 & -0.006 \\
\hline & $(0.038)$ & $(0.045)$ & $(0.056)$ & $(0.068)$ & & $(0.06)$ & $(0.05)$ & $(0.039)$ \\
\hline
\end{tabular}

Notes: Regressions are Ordered Logits. The dependent variable is 'self-reported satisfaction'. *, ** and *** indicate significance at the $10 \%, 5 \%$ and $1 \%$ level. Clustered standard errors are reported in parenthesis. Year and country dummies included.

\section{References}

Argue, J.C. (1983). Benefits of the 1984 Olympics. Business Forum, Fall 1983.

Baade, R. (1996). Professional sports as catalysts for metropolitan economic development. Journal of Urban Affairs, 18(1), 1-17.

Baade, R.A. and Dye, R.F. (1990). The impact of stadiums and professional sports on metropolitan area development. Growth and Change, 21(2), 1-14.

Baade, R.A. and Matheson, V.A. (2002). Bidding for the Olympics: Fool's Gold?. In C.P. Barros, M. Ibrahim, and S. Szymanski (Eds.), Transatlantic Sport (pp. 127-151). Edward Elgar Publishing, London.

Balmer, N.J., Nevill, A.M. and Williams, A.M. (2001). Home Advantage in the Winter Olympics (1908-1998). Journal of Sports Sciences, 19, 129-139.

Balmer, N.J., Nevill, A.M. and Williams, A.M. (2003). Modelling Home Advantage in the Summer Olympic Games. Journal of Sports Sciences, 21, 469-478.

Bernard, A.B. and Busse, M.R. (2004) Who Wins the Olympic Games: Economic Resources and Medal Totals. The Review of Economics and Statistics, 86(1), 413-417.

Bertrand, M. and Mullainathan, S. (2001). Do People Mean What they Say? Implications for Subjective Survey Data. American Economic Review, 91(2), May 2001, 67-72. 
Blake, A. (2005). The Economic Impact of the London 2012 Olympics. Christel DeHaan Tourism and Travel Research Institute, Nottingham University Business School, 2005/5. www.nottingham.ac.uk/ttri/olympics project.htm .

Blanchflower, D.G. and Oswald, A.J. (2000). Well-Being Over Time in Britain and the USA. National Bureau of Economic Research, Working Paper No. 7487.

Blanchflower, D.G. and Oswald, A.J. (2004). Money, Sex and Happiness: An Empirical Study. Scandinavian Journal of Economics, 106(3), 393-415.

Blanchflower, D.G. and Oswald, A.J. (2008). Hypertension and happiness across nations. Journal of Health Economics. 27, 218-233.

Burbank, M.J., Andranovich, G. and Heying, C.H. (2002). Mega-Events: Urban Development and Public Policy. The Review of Policy Research, 19(3), 179-202.

Carroll, D., Ebrahim, S., Tilling, K., Macleod, J. and Davey, G. (2002). Admissions for myocardial infarction and World Cup football: Database survey. British Medical Journal, 325, 1439-1442.

Chalkley, B. and Essex, S. (1999). Urban Development through Hosting International Events: A History of the Olympic Games. Planning Perspectives, 14, 369-394.

Chapin, T. (2002). Identifying the Real Costs and Benefits of Sports Facilities. Lincoln Institute of Land and Policy, Working Paper No: WP02TC1. www.lincolninst.edu/pubs/dl/671_chapin-web.pdf .

Clark, A.E. and Oswald, A.J. (1994). Unhappiness and Unemployment. The Economic Journal, 104(424), May 1994, 648-659.

Clark, A.E. and Oswald, A.J. (1996). Satisfaction and Comparison Income. Journal of Public Economics, 61(3), 359-381.

Coates, D.C. and Humphreys, B.R. (1999). The Growth Effects of Sport Franchises, Stadia and Arenas. Journal of Policy Analysis and Management, 18(4), 601-624.

Coates, D.C. and Humphreys, B.R. (2003). The Effect of Professional Sports on Earnings of Individuals: Evidence from Microeconomic Data. UMBC Economics Department, Working Paper 03-104.

Crompton, J.L. (1995). Economic Impact Analysis of Sports Facilities and Events: Eleven Sources of Misapplication. Journal of Sport Management, 9, 14-35.

Crompton, J.L. (2001). Public Subsidies to Professional Team Sport Facilities in the USA. In C. Gratton and I.P. Henry (Eds.), Sport in the City: The Role of Sport in Economic and Social Regeneration (pp. 35-45).Routledge publication.

Damisch, L., Mussweiler, T. and Plessner, H. (2006). Olympic Medals as Fruits of Comparison? Assimilation and Contrast in Sequential Performance Judgments. Journal of Experimental Psychology: Applied, 12(3), 166-178.

DCMS/Strategy Unit (2002). Game Plan: A Strategy for Delivering Government's Sport and Physical Activity Objectives, Department for Culture, Media and Sport/Strategy Unit, December 2002. www.sportdevelopment.org.uk/gameplan2002.pdf.

Di Tella, R. and MacCulloch, R.J. (2005a). Partisan Social Happiness. The Review of Economic Studies, 72(2), 367-393.

Di Tella, R. and MacCulloch, R.J. (2005b). Gross National Happiness as an Answer to the Easterlin Paradox?. Mimeo, Harvard Business School, November 2005. www.people.hbs.edu/rditella/papers/WPGNHappiness.pdf .

Di Tella, R. and MacCulloch, R.J. (2006). Some Uses of Happiness Data in Economics. Journal of Economic Perspectives, 20(1), 25-46.

Di Tella, R., MacCulloch, R.J. and Oswald, A.J. (2001). Preferences Over Inflation and Undemployment: Evidence from Surveys of Happiness. American Economic Review, 91(1), 335-341.

Di Tella, R., MacCulloch, R.J. and Oswald, A.J. (2003). The Macroeconomics of Happiness. The Review of Economics and Statistics, 85(4), 809-827. 
Easterlin, R.A. (1974). Does Economic Growth Improve Human Lot? Some Empirical Evidence, in Nations and Households. In P.A. David and M.W. Reder (Eds.), Economic Growth: Essays in Honour of Moses Abramowitz. Academic Press, New York and London.

Easterlin, R.A. (1995). Will Raising the Incomes of All Increase the Happiness of All?. Journal of Economic Behavior and Organization, 27(1), 35-48.

Easterlin, R.A. (2003). Explaining Happiness. Proceedings of the National Academy of Sciences, 100(19), 1176-1183.

Easterlin, R.A. (2005). Building a Better Theory of Well-Being. In L. Bruni and P.L. Porta (Eds.) Economics and Happiness: Framing the Analysis (pp. 29-64). Oxford University Press.

Essex, S. and Chalkley, B. (1998). Olympic Games: Catalyst of Urban Change. Leisure Studies, 17, 187-206.

Essex, S. and Chalkley, B. (2003). Urban Transformation from Hosting the Olympic Games, University Lecture on the Olympics, Barcelona, Centre d'Estudis Olimpics (UAB), International Chair in Olympism (IOC-UAB). http://olympicstudies.uab.es/lectures/web/pdf/essex.pdf .

Fernquist, R.M. (2000). An Aggregate Analysis of Professional Sports, Suicide, and homicide rates: 30 US metropolitan areas, 1971-1990. Aggression and Violent Behavior, 5(4), 329-341.

Frank, R.H. (2005). Does Absolute Income Matter?. In L. Bruni and P.L. Porta (Eds.) Economics and Happiness: Framing the Analysis (pp. 65-90). Oxford University Press.

Frey, B.S. and Stutzer, A. (2000). Happiness, Economy and Institutions. The Economic Journal, 110(466), 918-938.

Frey, B.S. and Stutzer, A. (2002). What Can Economists Learn from Happiness Research?. Journal of Economic Literature, 40(2), 402-435.

Frey, B.S. and Stutzer, A. (2005) Testing Theories of Happiness. In L. Bruni and P.L. Porta (Eds.) Economics and Happiness: Framing the Analysis (pp. 116-146). Oxford University Press.

Frey, B.S., Benesch, C. and Stutzer, A. (2007). Does Watching TV Make us Happy?. Journal of Economic Psychology, 28, 283-313.

Frey, B.S., Luechinger, S. and Stutzer, A. (2004). Valuing Public Goods: The Life Satisfaction Approach. Institute for Empirical Research in Economics, Working Paper No. 184, March 2004, University of Zurich.

Greene, W.H. (2003) Econometric Analysis, $5^{\text {th }}$ edition, Prentice Hall, US.

Grimes, A.R., Kelly, W.J. and Rubin, P.H. (1974). A Socioeconomic Model of National Olympic Performance. Social Science Quarterly, 55(3), 777-783.

Hall, C.M. (2006). Urban Entrepreneurship, Corporate Interests and Sports Mega-Events: The Thin Policies of Competitiveness within the Hard Outcomes of Neoliberalism. In J. Horne and W. Manzenreiter (Eds.) Sports Mega-Events: Social Scientific Analyses of a Global Phenomenon (pp. 59-70). Blackwell Publishing Ltd.

Hoffmann, R., Ging, L.C. and Ramasany, B. (2002). Public Policy and Olympic Success. Applied Economic Letters, 9, 545-548.

Hoffmann, R., Ging, L.C. and Ramasany, B. (2002). The Socio-Economic Determinants of International Soccer Performance. Journal of Applied Economics, 5(2), 253-272.

Hoffmann, R., Ging, L.C. and Ramasany, B. (2004). Olympic Success and ASEAN Countries: Economic Analysis and Policy Implications. Journal of Sports Economics, 5(3), 262-276.

Hoffmann, R., Ging, L.C., Matheson, V. and Ramasany, B. (2006). International Women's Football and Gender Inequality. Applied Economics Letters, 13(15), 999-1001.

Houston, R.G. and Wilson, D.P. (2002). Income, Leisure and Proficiency: An Economic Study of Football Performance. Applied Economics Letters, 9, 939-943.

Ingerson, L. (2001). A Comparison of the Economic Contribution of Hallmark Sporting and Performing Arts Events. In C. Gratton and I.P. Henry (Eds.), Sport in the City: The Role of Sport in Economic and Social Regeneration (pp. 46-59). Routledge publication. 
Johnson, D.K.N. and Ali, A. (2000). Coming to Play or Coming to Win: Participation and Success at the Olympic Games. Wellesley College, Department of Economics Working Paper 2000-10, September 2000.

Johnson, D.K.N. and Ali, A. (2004). A Tale of Two Seasons: Participation and Medal Counts at the Summer and Winter Olympic Games. Social Science Quarterly, 85(4), 974-993.

Kahneman, D. and Krueger, A.B. (2006). Developments in the Measurement of Subjective WellBeing. Journal of Economic Perspectives, 20(1), 3-24.

Kartakoullis, N., Papanikos, G. and Karlis, G. (2003). City and Sport Marketing Strategy: The Case of Athens 2004. The Sport Journal, 6(2), Spring 2003. www.thesportjournal.org/2003Journal/Vol6-No2/athens.asp .

Kirkup, W. and Merrick, D.W. (2003). A matter of life and death: population mortality and football results. Journal of Epidemiology and Community Health, 57, 429-432.

Kuper, G. and Sterken, E. (2001). Olympic Participation and Performance since 1896. CCSO Working Papers, number 200104, University of Groningen, CCSO Centre for Economic Research. http://ccso.eldoc.ub.rug.nl/FILES/root/2001/200104/200104.pdf .

Layard, R. (2005a). Happiness: Lessons from a New Science. Penguin Books Ltd, London, England.

Layard, R. (2005b). Rethinking Public Economics: The Implications of Rivalry and Habit. In L. Bruni and P.L. Porta (Eds.) Economics and Happiness: Framing the Analysis (pp. 147-169). Oxford University Press.

Leeds, E.M. and Leeds, M.A. (2007). International Soccer Success and National Institutions. International Association of Sports Economics, Working Paper Series, No. 07-02, March 2007. www.holycross.edu/departments/economics/RePEc/spe/Leeds_Soccer.pdf .

Lertwachara, K. and Cochran J.J. (2007). An Event Study of the Economic Impact of Professional Sport Franchises on Local US Economies. Journal of Sports Economics, 8(3), 244-254.

Luttmer, E.F.P. (2005). Neighbors as Negatives: Relative Earnings and Well-Being. The Quarterly Journal of Economics, 120(3), 963-1002.

Maenning, W. and Porsche, M. (2008). The Feel-Good Factor at Mega Sports Events. Recommendations for Public and Private Administration Informed by the Experience of the FIFA World Cup 2006. Hamburg Contemporary Economic Discussions, No. 18, Faculty of Economics and Social Sciences, Universitat Hamburg. www.uni-hamburg.de/onTEAM/grafik/1098966615/HCED-18.pdf .

Manzenreiter, W. and Horne, J. (2005). Public Policy, Sports Investments and Regional Development Initiatives in Japan. In J. Nauright and S. Schimmel (Eds.) The Political Economy of Sport (pp. 152-182). Palgrave MacMillan.

Matheson, V.A. (2002). Upon Further Review: An Examination of Sporting Event Economic Impact Studies. The Sport Journal, 5(1), Spring 2002. www.thesportjournal.org/article/uponfurther-review-examination-sporting-event-economic-impact-studies .

Matheson, V.A. (2006). Mega-Events: The Effect of the World's Biggest Sporting Events on Local, Regional and National Economies. International Association of Sports Economists, Working Paper Series, No. 06-22, October 2006. www.holycross.edu/departments/economics/RePEc/spe/Matheson_MegaEvents.pdf.

Matheson, V.A. and Baade, R.A. (2004). Mega-Sporting Event in developing Nations: Playing the Way to Prosperity?. College of the Holy Cross, Department of Economics Faculty Research Series, Working Paper No. 04-04. www.holycross.edu/departments/economics/RePEc/Matheson_Prosperity.pdf .

Medvec, V.H., Madey, S.F. and Gilovich, T. (1995). When less is more: Counterfactual thinking and satisfaction among Olympic medalists. Journal of Personality and Social Psychology, 69(4), 603-610. 
Moosa, I.A. and Smith, L. (2004). Economic Development Indicators as Determinants of Medal Winning at the Sydney Olympics: An Extreme Bounds Analysis. Australian Economic Papers, 43(3), 288-301.

de Moragas, M., Rivenburgh, N. and Garcia, N. (1995). Television and the Construction of Identity: Barcelona, Olympic Host. In M. de Moragas and M. Botella (Eds.), The Keys to Success: the Social, Sporting, Economic, and Communications Impact of Barcelona '92 (pp. 76-106). Servei de Publicacions de la UAB. http://olympicstudies.uab.es/pdf/wp033_eng.pdf.

Oswald, A.J. (1997). Happiness and Economic Performance. The Economic Journal, 107(445), 1815-1831.

Oswald, A.J. and Powdthavee, N. (2006). Does Happiness Adapt? A Longitudinal Study of Disability with Implications for Economists and Judges. IZA - Institute for the Study of Labor, Discussion Paper Series, No. 2208, July 2006.

van Praag, B.M.S. (1991). Ordinal and Cardinal Utility: An Integration of the two Dimensions of the Welfare Concept. Journal of Econometrics, 50, 69-89.

PricewaterhouseCoopers (2004). The Economic Impact of the Olympic Games, European Economic Outlook, Chapter III, June 2004. www.accountingnet.ie/content/uploads/pwc_eeo_jun04_1_.pdf .

Rappaport, J. and Wilerson, C. (2001). What are the Benefits of Hosting a Major League Sports Franchise?. Federal Reserve Bank of Kansas City, First Quarter 2001, Online Article: www.kansascityfed.org/publicat/econrev/PDF/1q01rapp.pdf .

Rathke, A. and Woitek, U. (2007). Economics and Olympics: An Efficiency Analysis. Institute for Empirical Research in Economics, Working Paper number 313, January 2007. www.iew.uzh.ch/wp/iewwp313.pdf .

Roberts, G. (2006). Accounting for Achievement in Athens: A Count Data Analysis of National Olympic Performance. Econometrics Working Paper EWP0602, Department of Economics, University of Victoria, Canada.

Roche, M. (1992). Mega-Events and Micro-Modernization: On the Sociology of the new Urban Tourism. The British Journal of Sociology, 43(4), 563-600.

Rosentraub, M. (1994). Sport and Downtown Development Strategy. Journal of Urban Affairs, 16(3), 228-239.

Siegfried, J. and Zimbalist, A. (2000). The Economics of Sports Facilities and their Communities. The Journal of Economic Perspectives, 14(3), 95-114.

Siegfried, J. and Zimbalist, A. (2002). A Note on the Local Economic Impact of Sports Expenditure. Journal of Sports Economics, 3(4), 361-366.

Siegfried, T. (2006). A Beautiful Math. Joseph Henry Press, Washington, D.C.

Solnick, S.J. and Hemenway, D. (1998). Is More Always Better? A Survey on Positional Concerns. Journal of Economic Behaviour and Organisation, 37, 373-383.

Tcha, M. and Pershin, V. (2003). Reconsidering Performance at the Summer Olympics and Revealed Comparative Advantage. Journal of Sports Economics, 4(3), 216-239.

Telloglou, T. (2004). The City of the Games. Hestia Publications, September 2004 (in Greek).

Thornley, A. (2002). Urban Regeneration and Sports Stadia. European Planning Studies, 10(7), 813-818.

Tobin, J. (1958). Estimation of Relationships for Limited Dependent Variables. Econometrica, 26 (1), 24-36.

Veenhoven, R. (2005). Happiness in Hardship. In Economics and Happiness: Framing the Analysis, edited by Bruni, L. and Porta, P.L., Oxford University Press.

Wallechinsky, D. (2004). The Complete Book of the Olympics. 2004 Edition, Aurum Press.

Whitson, D. (2004). Bringing the World to Canada: 'The Periphery of the Centre'. Third World Quarterly, 25(7), 1215-1232.

Whitson, D. and Horne, J. (2006). Underestimated Costs and Overestimated Benefits? Comparing the Outcomes of Sports Mega-Events in Canada and Japan. In J. Horne and W. Manzenreiter 
(Eds.), Sports Mega-Events: Social Scientific Analyses of a Global Phenomenon (pp. 73-89). Blackwell Publishing Ltd.

Wilbert-Lampen, U., Leistner, D., Greven, S., Pohl, T., Sper, S., Völker, C., Güthlin, D., Plasse, A., Knez, A., Küchenhoff, H. and Steinbeck, G. (2008). Cardiovascular events during World Cup soccer. The New England Journal of Medicine, 358, 475-483.

Winkelmann, L. and Winkelmann, R. (1998). Why are the Unemployed so Unhappy? Evidence from Panel Data. Economica, 65(257), 1-15.

Witte, D.R., Bots, M.L., Hoes, A.W. and Grobbee, D.E. (2000). Cardiovascular mortality in Dutch men during 1996 European football championship: Longitudinal population study. British Medical Journal, 321, 1552-1554.

Wooldridge, J.M. (2002). Econometric Analysis of Cross Section and Panel Data. MIT Press. 